\author{
Arkadiusz $\operatorname{Trzos}^{\mathrm{a}), \mathrm{b})^{*},}$ Karol Łyzińskia),c), Kamil Jurowskia) \\ a) Jagiellonian University Medical College, The Chair of Anaesthesiology and Intensive Care, The Department of Disaster Medicine \\ and Emergency Care / Uniwersytet Jagielloński Collegium Medicum, Wydział Lekarski, Katedra Anestezjologii i Intensywnej \\ Terapii, Zakład Medycyny Katastrof i Pomocy Doraźnej \\ b) Atmed Medycyna i Edukacja \\ c) Krakow Emergency Medical Services / Krakowskie Pogotowie Ratunkowe \\ *Corresponding author / Autor korespondencyjny: a.trzos@uj.edu.pl
}

\title{
Emergency Medical Services in CBRNE/HAZMAT Incidents
}

\section{Ratownictwo medyczne w zdarzeniach CBRNE/HAZMAT}

\begin{abstract}
Aim: The purpose of the study is to work out a new emergency medical service (EMS) tactic to be employed in CBRNE/HAZMAT incidents, which would allow performing emergency medical procedures in the area so far inaccessible to the State Emergency Medical System (Polish abbreviation: PRM). Project and methods: Incidents involving new hazardous materials, especially terrorist ones, demand emergency services to be well prepared in order to respond accordingly. Latest technological advances regarding both personal protective equipment (PPE) for preventing contamination and respiratory protection equipment bring effective and safe methods of medical professionals' protection at every stage of rescue operations being performed. The research study was conducted in 2016-2018 and its main focus was on providing medical care at all stages of rescue operations. The CBRNE/HAZMAT incident procedures of the State Emergency Medical System (PRM), the National Firefighting and Rescue System (KSRG), the Bureau of Anti-Terrorist Operations of the National Police Headquarters (BOA KGP) and the Epidemiological Response Centre of the Polish Armed Forces (CRESZ) were thoroughly analysed. An analysis of procedural shortcomings within rescue operations of all services was also conducted. In addition, the PPE for preventing contamination and the respiratory protection equipment that is used by various emergency services and may also be applied within PRM operations was thoroughly examined.

Results: Based on the study, a new EMS tactic was developed using the available PPE, a management system of rescue operations and a model of organisation of any operations. The in-depth analysis of PPE for preventing contamination and respiratory protection equipment indicated new solutions and methods for protecting professionals of the State Emergency Medical System (PRM) while providing pre-hospital and hospital care (in Hospital Emergency Departments). A set of training drills employing new tactics and PPE indicated real possibilities to transfer new solutions to EMS that would compensate the shortcomings identified within the procedures of responses at the subsequent stages of CBRNE/HAZMAT incidents.

Conclusions: The suggested tactic of emergency medical services shall enhance the effectiveness of the emergency rescue system in CBRNE/HAZMAT incidents as it enables emergency medical procedures (Polish abbreviation: MCR) to be more promptly performed in patients with life-threatening conditions, along with providing medical care at all stages of rescue operations.

Keywords: CBRNE, HAZMAT, Personal Protective Equipment (PPE), PRM system

Type of article: short scientific report
\end{abstract}

Received: 10.09.2019; Reviewed: 12.11.2019; Accepted: 17.12.2019;

Authors`s ORCID IDs: A. Trzos - 0000-0002-4390-0901; K. Łyziński - 0000-0003-3292-2459; K. Jurowski-0000-0003-0310-2849;

Percentage contributon: A. Trzos - 60\%; K. Łyziński - 30\%; K. Jurowski - 10\%;

Please cite as: SFT Vol. 54 Issue 2, 2019, pp. 142-159, https://doi.org/10.12845/sft.54.2.2019.11;

This is an open access article under the CC BY-SA 4.0 license (https://creativecommons.org/licenses/by-sa/4.0/).

\section{ABSTRAKT}

Cel: Celem badania było wypracowanie nowej taktyki ratownictwa medycznego działającego w warunkach zdarzeń CBRNE/HAZMAT, pozwalającej na podjęcie medycznych czynności ratunkowych (MCR) w obszarze dotychczas niedostępnym dla systemu Państwowe Ratownictwo Medyczne (PRM). Projekt i metody: Powstanie nowych zagrożeń ze strony materiałów niebezpiecznych, zwłaszcza zagrożeń o charakterze terrorystycznym, wymusza właściwe przygotowanie służb ratowniczych do reagowania. Postęp techniczny w obszarze środków ochrony przed skażeniami i środków ochrony dróg oddechowych pozwala obecnie na opracowanie bezpiecznych i skutecznych metod ochrony personelu medycznego. Badanie przeprowadzone zostało w latach 2016-2018. Skupiono się w nim nad możliwością udzielania pomocy medycznej na wszystkich etapach działań ratowniczych. Przeanalizowano procedury postępowania systemu PRM, Krajowego Systemu Ratowniczo-Gaśniczego (KSRG) i jednostek kontrterrorystcznych Biura Operacji Antyterrorystycznych Komendy Głównej Policji (BOA KGP), Centrum Reagowania Epidemiologicznego Sił Zbrojnych RP (CRESZ) przewidzianych do wykorzystania w incydentach CBRNE/HAZMAT. Dokonano analizy luk w obszarze udzielania pomocy medycznej poszkodowanym w ramach dotychczas stosowanej 
taktyki działania każdej ze służb. W trakcie badania przeanalizowano indywidualne środki ochrony przed skażeniami i środki ochrony dróg oddechowych wykorzystywane w poszczególnych służbach pod kątem możliwości ich zastosowania w obszarze systemu PRM.

Wyniki: Na podstawie przeprowadzonych badań wypracowano nową taktykę ratownictwa medycznego, opierającą się na wyposażeniu w indywidualne środki ochrony, nowym systemie zarządzania i nowym modelu organizacji działań. Prowadzona analiza możliwości wykorzystania indywidualnych środków ochrony przed skażeniami i środków ochrony dróg oddechowych pozwoliła na wypracowanie nowych zasad ochrony personelu medycznego systemu Państwowe Ratownictwo Medyczne. Przeprowadzone ćwiczenia wykazały możliwość implementacji nowych rozwiązań do systemu ratowniczego oraz uzupełnienie procedur postępowania na kolejnych etapach działań ratowniczych w zdarzeniach CBRNE/HAZMAT.

Wnioski: Proponowana nowa taktyka ratownictwa medycznego poprawia efektywność systemu ratowniczego w zdarzeniach CBRNE/HAZMAT, poprzez umożliwienie wcześniejszego podjęcia medycznych czynności ratunkowych w stanach zagrożenia życia oraz zabezpieczenia medycznego pacjentów na wszystkich etapach prowadzenia działań ratowniczych.

Słowa kluczowe: CBRNE, HAZMAT, środki ochrony indywidualnej (ŚOI), system PRM

Typ artykułu: doniesienie wstępne

Przyjęty: 10.09.2019; Zrecenzowany: 12.11.2019; Zatwierdzony: 17.12.2019;

Identyfikatory ORCID autorów: A. Trzos - 0000-0002-4390-0901; K. Łyziński - 0000-0003-3292-2459; K. Jurowski - 0000-0003-0310-2849;

Procentowy wkład merytoryczny: A. Trzos - 60\%; K. Łyziński - 30\%; K. Jurowski - 10\%

Proszę cytować: SFT Vol. 54 Issue 2, 2019, pp. 142-159, https://doi.org/10.12845/sft.54.2.2019.11;

This is an open access article under the CC BY-SA 4.0 license (https://creativecommons.org/licenses/by-sa/4.0/).

\section{Introduction}

The National Firefighting and Rescue System, according to Polish legislation, (Polish: Krajowy System Ratowniczo-Gaśniczy, KSRG) responds to hazardous materials incidents [1-2] and cooperates with the police units, the State Emergency Medical System (Państwowe Ratownictwo Medyczne, PRM) and specialised military units if needed to maintain its effective performance. They all share common procedures of operations that begin with a received emergency call, continue while performing any rescue operations at the incident scene and transferring the casualty to the hospital, and end with medical treatment provided in specialist medical centres. Many factors may impede communication between these services (and in consequence determine an effective management of rescue operations) as each group represents different objectives and operational methods, scopes and skills, as well as equipment and training. Constant advances in management and control systems, personal protective equipment (PPE) for preventing contamination, respiratory protection equipment, detection and hazardous material identification systems, decontamination methods, transport procedures and medical treatment have encouraged changes in the model of responses in the events where additional threats resulting from the presence of hazardous materials are involved. Currently, in order to improve operational efficiency, the emergency medical system is undergoing considerable changes which mainly refer to the medical professionals' approach.

\section{Challenge}

Hazardous materials are expected to become a major threat for the population in the 21 st century [3-6] as predicted by researchers whose main focus is on current and impending threats. This stems from the fact that biological, chemical, ra-

\section{Wprowadzenie}

Krajowy System Ratowniczo-Gaśniczy (KSRG) ustawowo jest powołany do reagowania na incydenty z udziałem materiałów niebezpiecznych [1-2]. Jednak w celu pełnego i skutecznego działania wymagana jest współpraca z jednostkami Policji, systemem Państwowego Ratownictwa Medycznego (PRM) oraz - w szczególnych sytuacjach - specjalistycznymi jednostkami wojska. Należy zauważyć, że występuje tutaj wzajemne przenikanie się procedur postępowania realizowanych przez poszczególne podmioty, począwszy od momentu przyjęcia zgłoszenia, rozpoczęcia i prowadzenia działań na miejscu zdarzenia, poprzez transport ofiar do szpitali, a kończąc na leczeniu w wyspecjalizowanym ośrodku medycznym. Na trudności we wzajemnym komunikowaniu i zrozumieniu (a w konsekwencji w sprawnym zarządzaniu działaniami ratowniczymi) wpływa wiele czynników. Można do nich zaliczyć przede wszystkim: różnorodność celów do osiągnięcia przez każdą ze służb, metody ich osiągania, różny zakres i możliwości realizowania swoich zadań, odmienności w wyposażeniu oraz wyszkoleniu poszczególnych służb. Stały postęp w rozwoju systemów zarządzania i kontroli, indywidualnego sprzętu ochronnego zabezpieczającego przed skażeniami i sprzętu ochrony dróg oddechowych, systemów detekcji i identyfikacji materiałów niebezpiecznych, środków i metod dekontaminacji, zasad transportu i możliwości leczenia, zmienia model reagowania w zdarzeniach, w których występują dodatkowe zagrożenia wynikające z obecności materiałów niebezpiecznych. Najwięcej modyfikacji, mających na celu zwiększenie efektywności działania, dokonuje się obecnie w systemie ratownictwa medycznego. Modyfikacje te obejmują - obok wyposażenia i korekty procedur postępowania - przede wszystkim zmianę mentalności personelu medycznego.

\section{Wyzwanie}

Według przewidywań naukowców zajmujących się problematyką współczesnych i nadchodzących zagrożeń, materiały niebezpieczne stanowić będą jedno z głównych zagrożeń dla ludności w XXI wieku [3-6]. Znajdują one swoje źródło w czynnikach biologicznych, che- 
diation and nuclear agents might be used as weapons of mass destruction (WMD) or be released into the environment in the course of technical breakdowns, which is the most probable occurrence in Poland. As reported by the National Headquarters of the State Fire Service, in 2016 there were 415 plants located in Poland which were likely to experience a serious industrial failure due to hazardous materials being stored. 179 plants were qualified as high-hazard worksites, and 236 as increased-risk worksites [7].

Exposure to hazardous materials may be dangerous both to incident casualties and medical rescue workers involved in providing medical care.

Much is yet to be done when it comes to training medical staff on how to effectively respond to the above mentioned threats. Various studies have revealed a gap in medical professionals' knowledge and skills at all stages (pre-hospital, early hospital and specialised care) [8-11]. There is a clear trend to introduce some changes to solve the problem, which was recognised by the Department of Disaster Medicine and Emergency Care, the Chair of Anaesthesiology and Intensive Care, at the Jagiellonian University Medical College in Krakow.

All the changes in environmental conditions which medical professionals need to face require an appropriate protection of rescue teams including the medical staff (depending on the type and size of the threat). They need to be provided with PPE, e.g., respiratory protection equipment and protective equipment to prevent contamination of the skin (protective suits). Accessibility to such a type of protective equipment changes the rescue responses. A conventional approach "it is dangerous so I am not in" is already gone. Nowadays, the medical rescue management related to hazardous materials incidents is no longer procedural but based on knowledge, risk analyses, and accurate management of available resources, and both the negative and potentially positive consequences are duly considered. Such a change stems from different society's expectations due to an increased awareness of existing threats and a different approach taken by medical professionals, resulting from a wider knowledge and accessibility of PPE to prevent contamination and respiratory protection equipment.

Emergency medical services define the term hazardous materials as each and every CBRN substance which is potentially life-threatening and hazardous to health, irrespective of whether a single or mass casualties may be involved, or general public health may be at stake. Thus, emergency medical services face the challenge of improving responses to the above events regardless of the type, size and number of casualties.

The medical staff may be exposed to hazardous materials in two types of events: accidental and intentional. The accidental event is caused by an accident, breakdown, fire or disaster - the so called HAZMAT (hazardous materials) [12]. The chemicals, especially toxic industrial chemicals, released to the environment are highly dangerous and lead to mass casualty incidents [3]. Another burning issue is the outbreaks of infectious diseases (epidemics) and the radiation threat. The Chernobyl nuclear power plant disaster in 1986 [13], the accident at the Three Mile Island nuclear power station in 1979 [14] or the dramatic consequences micznych, radiacyjnych i nuklearnych, które mogą być użyte jako broń masowego rażenia lub zostać uwolnione w wyniku awarii technicznych (co jest najbardziej aktualnym zagrożeniem w warunkach polskich). Tylko według danych Komendy Głównej PSP z 2016 roku w Polsce prowadziło działalność 415 zakładów przemysłowych, w których istnieje możliwość wystąpienia poważnej awarii przemysłowej ze względu na przechowywane w nich materiałów niebezpiecznych. Do zakładów dużego ryzyka (ZDR) zaliczono 179 placówek, a 236 do zakładów zwiększonego ryzyka (ZZR) [7].

Ekspozycja na materiały niebezpieczne powoduje ryzyko dla życia i zdrowia nie tylko samych uczestników zdarzenia, ale także personelu ratowniczego zaangażowanego $\mathrm{w}$ udzielanie pomocy medycznej.

Przygotowanie personelu medycznego do działań wobec opisywanych zagrożeń jest jeszcze dalekie od doskonałości. Liczne badania potwierdzają lukę wiedzy i umiejętności wśród personelu medycznego wszystkich poziomów (opieka przedszpitalna, wczesnoszpitalna, specjalistyczna) [8-11]. Jednocześnie widoczna jest także tendencja do zmiany i rozwiązania tego problemu. Został on także dostrzeżony w Zakładzie Medycyny Katastrof i Pomocy Doraźnej, Wydziału Lekarskiego, Uniwersytetu Jagiellońskiego Collegium Medicum w Krakowie.

Zmiana warunków środowiskowych, w których przychodzi działać służbom medycznym wymaga odpowiedniego zabezpieczenia personelu ratowniczego ( $w$ tym medycznego) - w zależności od rodzaju i wielkości zagrożenia - w środki ochrony indywidualnej (ŚOI), tj. środki ochrony dróg oddechowych i środki ochrony przed skażeniem skóry (kombinezony ochronne). Dostępność tego typu środków ochrony pozwala na zmianę sposobu reagowania ratownictwa medycznego. Tradycyjna postawa personelu medycznego wyrażająca się zdaniem „jest niebezpiecznie, więc nie wchodzę" zdecydowanie przechodzi już do historii. Współcześnie, w obszarze zarządzania, podejście do problematyki udzielania pomocy poszkodowanym w incydentach z udziałem materiałów niebezpiecznych jest mniej proceduralne, bardziej otwarte, oparte na wiedzy, analizie ryzyka, zarządzaniu dostępnymi zasobami, $w$ tym ocenie negatywnych konsekwencji i potencjalnych korzyści. Zmiana podejścia wymuszona została zarówno wzrostem oczekiwań społeczeństwa wynikającym z większej świadomości zagrożeń, jak i zmiany podejścia personelu medycznego, którego przyczyny należy szukać w rozwoju wiedzy z tego obszaru ratownictwa oraz $\mathrm{w}$ świadomości dostępności indywidualnych środków ochrony przed skażeniami i środków ochrony dróg oddechowych pozwalających na bezpieczne działanie.

W ratownictwie medycznym pod pojęciem materiału niebezpiecznego rozumie się każdą substancję pochodzenia biologicznego, chemicznego, radiacyjnego i nuklearnego, która działając na organizm, powoduje poważne zagrożenie zdrowia lub życia - niezależnie od tego, czy stanowi zagrożenie wyłącznie dla pojedynczej osoby czy ma możliwość wywołania strat masowych, czy wręcz stanowi zagrożenie dla zdrowia publicznego. Stąd ratownictwo medyczne podejmuje przygotowania do reagowania na tego typu zdarzenia niezależnie od jego charakteru, rozmiaru i liczby ofiar.

Personel medyczny może zostać narażony na kontakt z materiatem niebezpiecznym w dwóch rodzajach zdarzeń. Pierwsze to zdarzenia powstałe w sposób przypadkowy, w konsekwencji wypadku, awarii, pożaru, katastrofy. Mówimy wtedy o zagrożeniach HAZMAT 
of tsunami on the Fukushima nuclear power plant in 2011 [15] are but a few examples of such incidents.

The second type of incidents involves medical staff's exposure to hazardous materials released intentionally. The release is done for military (via combat operations), criminal or terrorist purposes. The emergency medical services use the CBRN acronym ( $C$ - chemical, $B$ - biology, $R$ - radiological, $N$ - Nuclear) [16] and since such incidents usually involve the use of explosives, the CBRNE acronym is used ( $E$ - explosive) [3], [17].

In intentional incidents, chemical weapons are used, e.g., sarin [3], [18] in Tokyo in 1995 or Novichok [3], [19] (Russian новичок - novice). Terrorist acts often involve the use of easily available poisons, toxic industrial chemicals (e.g., chlorine, ammonia) or biological agents (e.g., anthrax spores, botulinum toxin).

The division into those groups in terms of rescue tactics and operational organisation is reasonable. No natural sequence of events, intercurrent tactical threats (firearms), a control factor (an assassin), secondary risks (secondary explosives), or the extensity and often multidimensionality of events - all these require different priorities of actions. In CBRNE incidents, the delegated police units (anti-terrorism units) are in most cases the leading service responsible for the organisation and operations. It is crucial to eliminate "the control factor" first. Once it has been eliminated and a pyrotechnic risk of the scene and participants have been assessed, the event should proceed almost naturally, becoming manageable for the emergency medical services. From that moment, the course of rescue actions in both CBRNE and HAZMAT incidents will be similar. There is no dramatic difference between those two types of incidents from the medical perspective as the medical treatment provided in both cases is comparable. Hence, it is vital to develop medical strategies and equip the medical staff adequately to allow them to respond effectively.

The ability to operate and cooperate with other services in CBRNE/HAZMAT indents becomes a paramount skill of emergency medical services facing existing and impending threats.

The emergency medical services operating worldwide have already changed their approach towards patient care and responses to critical hazards in every zone and at every stage of rescue operations [20-21]. (ang. Hazardous Materials) [12]. W tej grupie zagrożeń szczególnie niebezpieczne są uwolnione do środowiska środki chemiczne, w tym toksyczne środki przemysłowe (TSP), które mogą powodować straty masowe [3]. Obok zagrożeń chemicznych coraz poważniejszym problemem staje się rozprzestrzenianie chorób zakaźnych (epidemie). Również zagrożenie radiacyjne pozostaje ciągle aktualne. Przykładem tego typu zdarzeń jest awaria w elektrowni jądrowej w Czarnobylu (1986) [13], wypadek w elektrowni jądrowej Three Mile Island (1979) [14] czy katastrofalny wpływ tsunami na elektrownię jądrową w Fukushimie (2011) [15].

W drugim typie zdarzeń personel medyczny narażony zostaje na materiały niebezpieczne uwolnione do środowiska w sposób intencjonalny. Uwolnienie następuje w celach militarnych (podczas prowadzonych działań bojowych), kryminalnych lub terrorystycznych. Dla tej grupy zdarzeń używany jest w ratownictwie medycznym akronim CBRN (ang. C - Chemical, $B$ - Biological, $R$ - Radiological, $N$ - Nuclear) [16]. Jako że w podobnych incydentach substancje niebezpieczne nierzadko rozprzestrzeniane są przy wykorzystaniu materiałów wybuchowych, tego typu zagrożenia określane są przy użyciu akronimu CBRNE (ang. E - Explosive) [3], [17].

W zagrożeniach intencjonalnych wykorzystywane są przede wszystkim bojowe środki trujące (BST), jak na przykład sarin użyty w 1995 roku w Tokio [3], [18] czy nowiczok, którym posłużono się w Salisbury w 2016 roku ( ros. новичок - nowicjusz) [3], [19]. Nie można jednak wykluczyć użycia w celach terrorystycznych trucizn ogólnie dostępnych, toksycznych środków przemysłowych (np. chloru, amoniaku), czy czynników pochodzenia biologicznego (np. przetrwalników wąglika, toksyny jadu kiełbasianego).

Podział zdarzeń na wymienione powyżej dwie grupy jest w pełni zrozumiały z punktu widzenia taktyki ratowniczej i sposobu organizacji działań. Brak naturalnego przebiegu zdarzenia, wspótistniejące zagrożenia taktyczne (broń palna), obecność czynnika sterującego zdarzeniem (zamachowiec), ryzyko wtórnych zagrożeń (wtórne ładunki wybuchowe), rozległość czy nierzadko wielopunktowość zdarzenia wymuszają odmienne priorytety działania. W zagrożeniach CBRNE odpowiedzialne za organizację i prowadzenie działań są najczęściej wydzielone jednostki policji (pododdziały kontrterrorystyczne). Ich kluczową rolą w pierwszej kolejności jest unieszkodliwienie czynnika sterującego zdarzeniem. Następnie przeprowadzana jest kontrola pirotechniczna miejsca i uczestników zdarzenia. Od tego momentu incydent będzie miał przebieg zbliżony do naturalnego, co pozwoli na zastosowanie ratowniczego systemu zarządzania. Scenariusz działań ratowniczych, zarówno w przypadku zdarzeń CBRNE, jak i HAZMAT będzie odtąd podobny. Dotyczy to również sposobu postępowania z pacjentami. Dlatego należy wypracować odpowiednią taktykę medyczną i propozycję wyposażenia personelu medycznego, pozwalających na skuteczne działanie w obu rodzajach zdarzeń.

W dobie już istniejących i nadchodzących w niedalekiej przyszłości zagrożeń umiejętność poprawnego działania i współdziałania ratownictwa medycznego $z$ innymi podmiotami w zdarzeniach CBRNE/HAZMAT staje się zatem ważną - wręcz priorytetową - sprawnością medycznych służb ratunkowych.

Obecnie światowe ratownictwo medyczne zmienia swoje podejście do opieki nad pacjentem i sposobem reagowania w sytuacjach krytycznych zagrożeń dla życia w każdej strefie i na każdym etapie postępowania ratowniczego [20-21]. 


\section{Research Material and Method}

The possible ways to improve the effectiveness of rescue operations in CBRNE/HAZMAT incidents were investigated. The research was conducted in the Department of Disaster Medicine and Emergency Care at the Jagiellonian University Medical College in Krakow in 2015-2018. The methodology of the research consisted of the following:

1) an analysis of source materials, i.e., the literature review of available procedures (both Polish and foreign);

2) a critical analysis of the existing procedures and equipment of the National Firefighting and Rescue System, the Bureau of Anti-Terrorist Operations of the National Police Headquarters and the Epidemiological Response Centre of the Polish Armed Forces;

3) a comparative analysis, i.e., direct observations of responses to CBRNE incidents of the Polish emergency medical services and Israeli services in Tel Aviv (2016);

4) paramedics of the National Firefighting and Rescue System, medical professionals of the National Emergency Medical Services, police officers of the Bureau of Anti-Terrorist Operations, and paramedics of the Epidemiological Response Centre took part in drills with the use of different types of protective suits to evaluate their utility. The drills were followed by the exchange of experiences and possible solutions were discussed.

Based on the research, a new tactical solution was developed as a result of preliminary pilot studies aiming at establishing new detailed procedures and protocols of EMS responses to CBRNE/HAZMAT incidents. The aforementioned objectives are to be achieved within the project titled "Developing National Strategies for Responses to CBRNE events - coordination and standardisation" which forms part of the Norway Grants funding scheme 2019-2024.

\section{Research Outcomes}

The new tactic is a combination of theoretical and practical skills used to manage accessible resources in order to accomplish the objective. Its nature depends on the organisational structure, the management system and logistics resources. The tactical solution assigns new tasks to the emergency medical services. The proposed changes are as follows:

- ensuring an early threat identification,

- securing the incident scene,

- evacuating casualties from the danger zone,

- performing triage, providing critical care services and preparing for decontamination,

- performing decontamination, patient supervision during the decontamination process and supervising its conduct,

- securing patients in medical stations and preparing them for transport,

\section{Materiał i metoda}

Badania miały na celu ocenę możliwości zwiększenia efektywności prowadzonych działań ratunkowych w zdarzeniach CBRNE/HAZMAT. Prace prowadzone były w Zakładzie Medycyny Katastrof i Pomocy Doraźnej Uniwersytetu Jagiellońskiego Collegium-Medicum w Krakowie w latach 2015-2018. Na metodykę badań składały się:

1) analiza materiału źródłowego tj. przegląd materiału i procedur postępowania dostępnych w literaturze przedmiotu (krajowej i zagranicznej);

2) krytyczna analiza funkcjonujących obecnie procedur postępowania i wyposażenia systemu Państwowe Ratownictwo Medyczne (PRM), Krajowego Systemu Ratowniczo-Gaśniczego (KSRG), jednostki kontrterrorystycznej Biura Operacji Antyterrorystycznych Komendy Głównej Policji (BOA KGP) oraz Centrum Reagowania Epidemiologicznego Sił Zbrojnych RP (CRESZ RP);

3) analiza porównawcza - obserwacja bezpośrednia sposobu reagowania na zagrożenia CBRNE polskich służb ratowniczych i służb izraelskich w Tel Avivie (2016 r.);

4) wspólne ćwiczenia z ratownikami sytemu KSRG, personelem medycznym systemu PRM, policjantami BOA KGP i ratownikami CRESZ; z zastosowaniem różnych typów kombinezonów ochronnych, ocena ich przydatności w badanych sytuacjach. Po ćwiczeniach wymieniono się doświadczeniami i poddano analizie możliwe rozwiązania.

Na podstawie przeprowadzonych badań wypracowano koncepcję nowej taktyki, która stanowi efekt pilotażowych badań wstępnych do opracowania szczegółowych procedur i protokołów postępowania dla ratownictwa medycznego w obszarze reagowania na zagrożenia CBRNE/HAZMAT. Wspomniane cele będą opracowywane w ramach projektu „Opracowanie krajowej strategii reagowania na zagrożenia CBRNE - koordynacja i standaryzacja" realizowanego w ramach Grantu Norweskiego w latach 2019-2024.

\section{Wyniki badań}

Taktyka to teoria i praktyka posługiwania się posiadanymi na miejscu zasobami dla osiągnięcia zamierzonego celu. Uzależniona jest ona ściśle od struktury organizacyjnej, systemu zarządzania i zasobów logistycznych. W ramach proponowanej nowej taktyki działania ratownictwo medyczne otrzymuje nowe zadania do wykonania. Proponowane zmiany obejmują następujące obszary.

- wstępne rozpoznanie zagrożenia,

- wstępne zabezpieczenie miejsca zdarzenia,

- ewakuację poszkodowanych ze strefy zagrożenia,

- triage, interwencje krytyczne i przygotowanie do dekontaminacji,

- dekontaminację, nadzór nad pacjentem w jej trakcie i kontrolę jej wykonania,

- zabezpieczenie pacjentów w punkcie medycznym i przygotowanie do transportu,

- podjęcie i prowadzenie „czystego" $\mathrm{i}$ „brudnego" transportu, 
- undertaking "clean" and "dirty" transport

- providing medical support for all rescue operations.

Some of the above tasks may be carried out by individual services, especially in the case of biological incidents, except for the occurrence of highly contagious diseases. In most CBRNE incidents, cooperation with the National Firefighting and Rescue System, police units and delegated military units (especially when chemical weapon agents, CWAs, are involved) is essential in military and terrorist incidents.
- zabezpieczenie medyczne prowadzonych działań ratowniczych.

Część z przedstawionych powyżej zadań będzie mogła być wykonywana przez ratowników bez wsparcia innych służb. Sytuacja ta dotyczyć będzie przede wszystkim zagrożeń biologicznych, z wyjątkiem podejrzenia o występowanie choroby wysoce zakaźnej szczególnie niebezpiecznej. W pozostałych przypadkach (CBRNE) wymagane będzie współdziałanie ratowników medycznych z systemem KSRG, pododdziałami policji i - w szczególnych sytuacjach - z wydzielonymi jednostkami wojska (użycie bojowych środków trujących, BST) w obszarach reagowania na zagrożenia militarne i terrorystyczne.

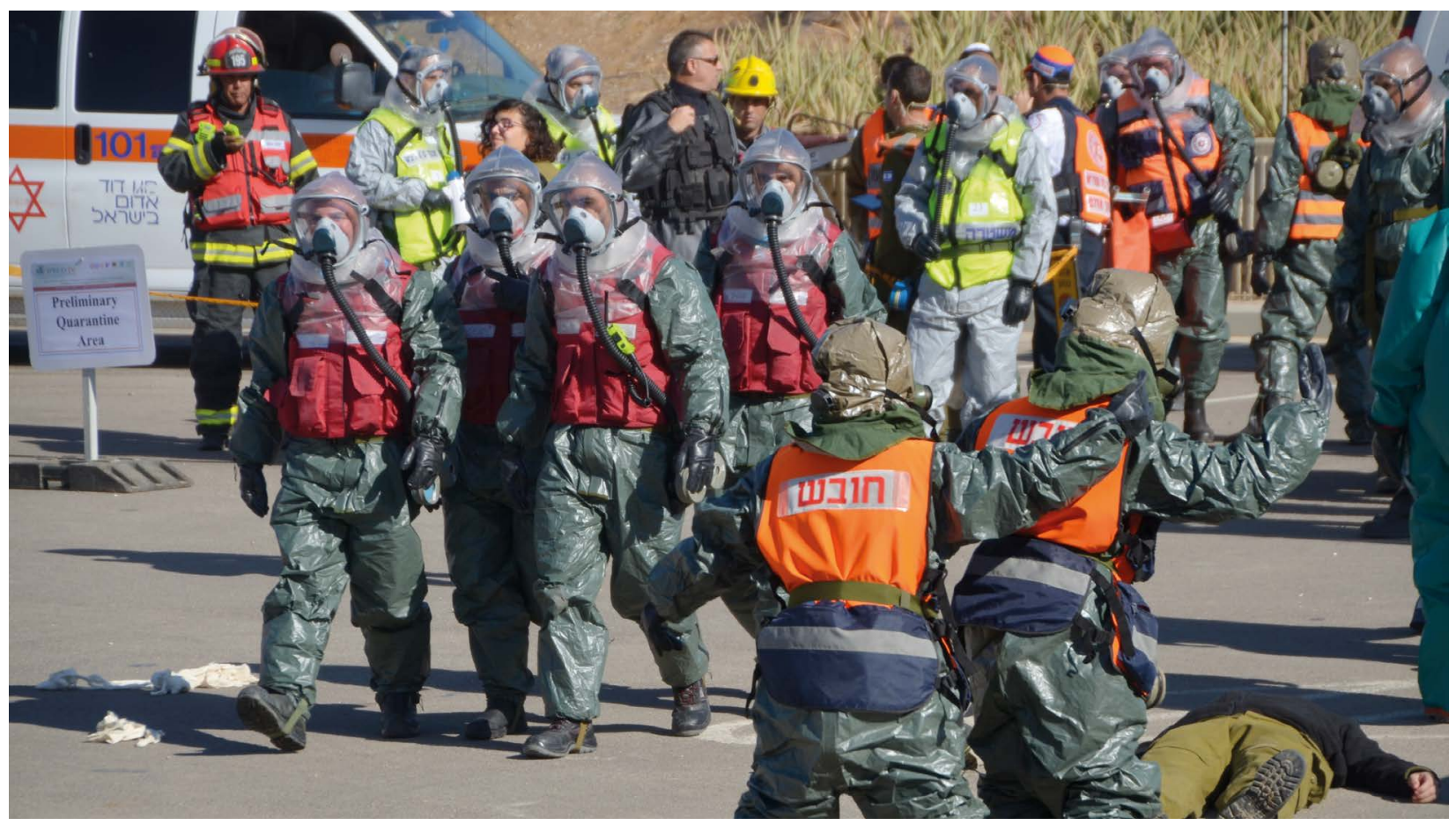

Figure 1. Medical teams entering the hot zone (Tel Aviv, Israel 2016)

Rycina 1. Wejście zespołów medycznych do strefy gorącej (Tel Awiw, Izrael, 2016)

Source: The authors' archives.

Źródło: Archiwum własne.

From the patient's perspective, it is crucial to eliminate exposure to the hazardous factor, to perform triage and to immediately start life-support activities if needed. In the event of HAZMAT contamination, a prompt evacuation from the danger zone, triage and early decontamination are essential.

\section{Organisation of Rescue Operations}

Three safety zones have been defined for the purposes of the management system of Emergency Medical Services and effective medical operations:

- the hot zone,
Z punktu widzenia pacjenta najważniejsze jest jak najszybsze przerwanie ekspozycji na działanie czynnika niebezpiecznego, a następnie przeprowadzenie triage'u i natychmiastowe podjęcie czynności resuscytacyjnych w grupie pacjentów tego wymagających. Priorytetem pozostaje ewakuacja ze strefy bezpośredniego zagrożenia, a następnie wykonanie triage'u i wstępnej dekontaminacji, jeśli doszło do skażenia materiałem niebezpiecznym.

\section{Organizacja działań ratunkowych}

Na potrzeby systemu zarządzania ratownictwa medycznego i efektywnego prowadzenia działań medycznych wyróżniono trzy strefy bezpieczeństwa:

- strefę gorącą, 
- the warm zone, and

- the cold zone.

In medical sciences the hot zone is defined as an area within which a casualty (or casualties) is exposed to a hazardous substance. Entering this zone requires certain safety conditions to be met, i.e., applying protection equipment to prevent contamination as well as respiratory protection equipment (see Figure 1).

Medical operations in chemical and radiation incidents performed in the hot zone are limited to life-support activities, e.g., haemorrhage control, airway management and securing the patient to allow safe transfer. Biological incidents require a different approach, and more advanced medical and rescue procedures where a specific biological (epidemic) threat has been identified. Biological incidents require a detailed analysis and a separate research paper.

The warm zone is an area in which a hazardous substance does not occur originally. This is, therefore, where the casualties are primarily directed. In the course of an evacuation process, a hazardous substance may be transferred into the evacuation path and an area which the casualties are transferred to. Thus, this zone requires additional PPE to be used by the paramedics involved. In the warm zone, preliminary triage, cardiopulmonary resuscitation (CPR), and basic and advanced life-support activities are performed. In addition, the type and order of decontamination must be determined and any preparation for decontamination procedures applied if required.

The cold zone is the remaining area in which the hazardous substance is not present in the quantity that would pose any danger to care providers equipped with basic protection equipment.

Such a zone division enables risk management and, therefore, a proper organisation of medical activities, staff and equipment resources management, including PPE for preventing contamination and respiratory protection equipment. The organisation of all operations in compliance with the described model is presented in Figure 2.

Existing threats demand that the 3-zone division be employed and that rescue operations be performed in all 3 zones, provided the operations are medically necessary and meet all the safety requirements. The way the medical staff is managed at the incident scene and in all zones is based on potential benefits in every zone, their competences in the field of medical care provision and the available PPE enabling them to provide care. The EMS management policy/strategy blends into the National Firefighting and Rescue System as well as provides grounds for the tactical decisions made by the police and military units.
- strefę ciepłą,

- strefę zimną.

W naukach medycznych strefa gorąca rozumiana jest jako obszar, w którym występuje substancja niebezpieczna i w którym znajduje się ofiara będąca pod jej działaniem. Wejście do strefy wymaga spełnienia określonych warunków bezpieczeństwa, w tym wykorzystania środków ochrony przed skażeniami i środków ochrony dróg oddechowych (ryc. 1).

Działania medyczne podczas incydentów chemicznych i radiacyjnych podejmowane w tej strefie są mocno ograniczone i sprowadzają się praktycznie do prostych czynności ratujących życie, np. tamowania krwotoku, zabezpieczenia drożności dróg oddechowych, zabezpieczenia pacjenta na czas ewakuacji. Zagrożenia biologiczne cechuje odmienna specyfika postępowania, wymuszająca wykonanie w miejscu rozpoznania poważnego zagrożenia biologicznego (epidemicznego) bardziej złożonych i zaawansowanych czynności ratowniczo-medycznych. Specyfika zagrożeń biologicznych wymaga szczegółowego omówienia w oddzielnym opracowaniu.

Strefa ciepła to obszar, w którym pierwotnie nie występuje już substancja niebezpieczna w środowisku. Stąd ewakuacja odbywa się właśnie do tej strefy, pierwotnie czystej. W wyniku ewakuacji substancja niebezpieczna może zostać rozproszona na drodze ewakuacji i w miejscu pozostawienia pacjenta. $Z$ tego powodu w strefie tej wymagane jest stosowanie przez ratowników medycznych delegowanych do udzielania pomocy dodatkowych indywidualnych środków ochrony. Jest to obszar przewidziany do wykonania wstępnego triage'u, resuscytacji krążeniowo-oddechowej i innych zabiegów podtrzymujących pacjenta przy życiu, zabezpieczenia jego podstawowych funkcji życiowych oraz określenia rodzaju i kolejności dekontaminacji, przygotowania do niej - jeżeli jest ona wymagana w danym zdarzeniu.

Strefa zimna to pozostały obszar, w którym nie występuje już substancja niebezpieczna w ilościach (stężeniu) stanowiących zagrożenie dla personelu medycznego stosującego rutynowe środki ochrony osobistej.

Podzielenie obszaru zdarzenia na strefy ułatwia zarządzanie ryzykiem, a w konsekwencji odpowiednią organizację działań medycznych, zarządzanie personelem medycznym i wykorzystanie zasobów logistycznych (sprzętowych), w tym indywidualnych środków ochrony przed skażeniami i ochrony dróg oddechowych. Organizację działań według opisanego modelu przedstawia rycina 2 .

W odpowiedzi na współczesne zagrożenia ratownictwo medyczne przewidziane jest do wykorzystania w każdej z wymienionych stref - o ile to działanie jest uzasadnione z medycznego punktu widzenia i są możliwości spełnienia niezbędnych warunków bezpieczeństwa. Sposób zarządzania personelem medycznym na miejscu zdarzenia i delegowanie go do poszczególnych stref uwzględnia zasadność i korzyści jego wykorzystania w konkretnych strefach, a także jego kompetencje w zakresie udzielania pomocy i dostępne środki ochrony osobistej to umożliwiające. Ratownictwo medyczne integruje swój model zarządzania $\mathrm{z}$ istniejącym na miejscu modelem kierowania KSRG, jak również z działaniami taktycznymi podejmowanymi przez pododdziały policji lub wojska. 


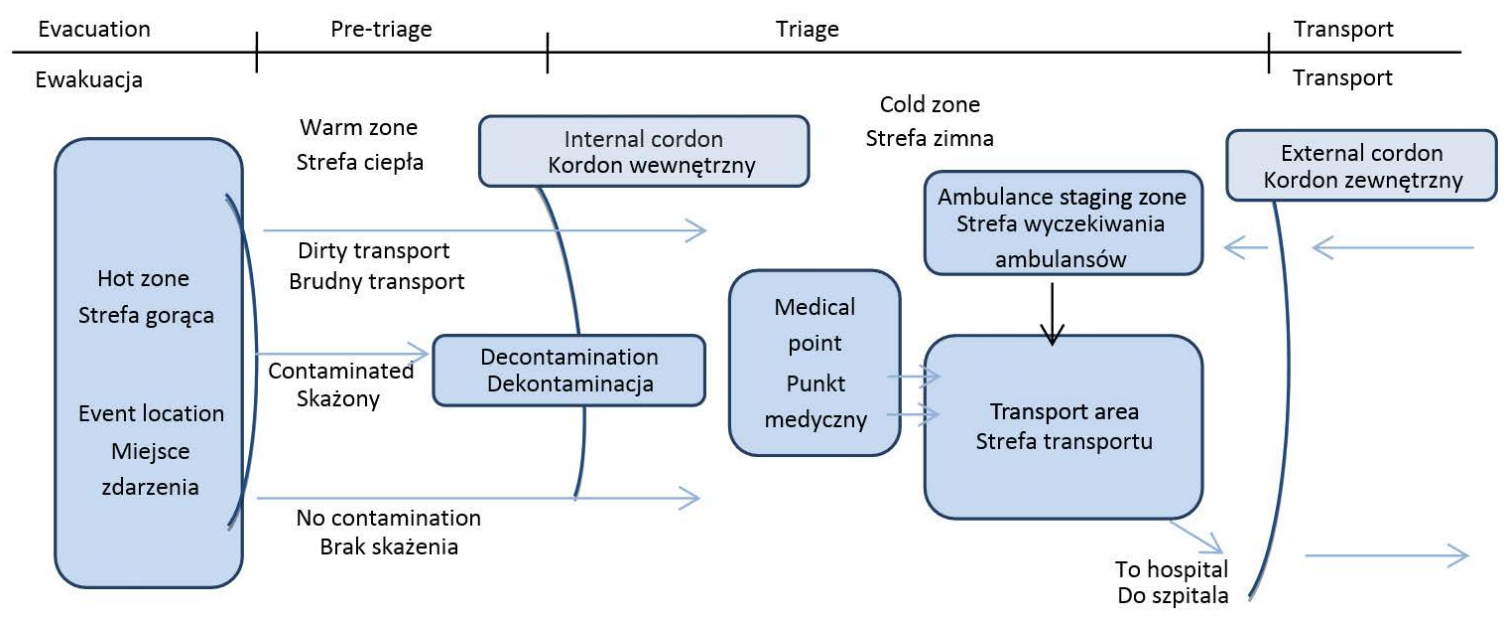

Figure 2. The organization of medical response to CBRNE/HAZMAT incidents Rycina 2. Organizacja działań ratunkowych w zdarzeniach CBRNE/HAZMAT Source: The authors' archives.

Źródło: Archiwum własne.

\section{Resource Management of PRM System}

A new approach has called for establishing task forces which are to perform specific tasks (functions) that form part of the irreplaceable sequence of operations. The basic functions are as follows:

- management / coordination,

- safety (new),

- triage,

- decontamination,

- medical treatment/procedures,

- transport,

- staging.

Each task force consists of METs or individuals (executors) and persons in control (duty-holders, task force coordinators).

The position of a medical operations coordinator involves the organisation of medical operations, developing medical tactics/tactical solutions for a specific incident, and the management of medical operations. A medical operations coordinator designates persons selected from heads/coordinators of emergency medical teams at the scene, assigns/delegates tasks and coordinates their cooperation. Then, the coordinator supervises the cooperation of a dispatcher of the State Emergency Medical System, the National Firefighting and Rescue System, while remaining in contact with the rescue operations coordinator, volunteers and support groups, etc. The medical operations coordinator reports directly to the rescue operations coordinator and performs all the assigned tasks in accordance with the strategy they previously agreed on. The medical operations coordinator decides upon establishing medical headquarters to help gather, process and reach necessary decisions (see Figure 3).

\section{Zarządzanie zasobami systemu PRM}

W nowej taktyce ratownictwa medycznego wypracowano grupy zadaniowe, które realizują określone zadania (funkcje) stanowiące pojedyncze ogniwa w łańcuchu niezbędnych do wykonania czynności. Podstawowe funkcje to:

- kierowanie/koordynacja,

- bezpieczeństwo (nowość),

- triage,

- dekontaminacja,

- leczenie,

- transport,

- odwód.

W każdej grupie zadaniowej znajdują się zespoły ratownictwa medycznego lub pojedyncze osoby realizujące określone zadania (wykonawcy) oraz osoby, które będą kierowały ich działaniem (osoby funkcyjne, kierownicy grup zadaniowych).

Rolą kierującego akcją medyczną (KAM) - wg obowiązującej nomenklatury - jest organizacja działań medycznych, wypracowanie optymalnej dla danego zdarzenia taktyki medycznej, zarządzanie medyczną częścią akcji ratowniczej. KAM wyznacza osoby do realizacji określonych zadań (funkcyjni) spośród kierowników przybywających na miejsce zespołów ratownictwa medycznego (ZRM). KAM stawia im zadania do wykonania i koordynuje współpracę pomiędzy nimi. W dalszej kolejności koordynuje współpracę z dyspozytorem systemu PRM, systemem KSRG, będąc w ścisłym kontakcie z kierującym działaniami ratowniczymi (KDR), wolontariuszami i grupami wsparcia itd. KAM podlega bezpośrednio pod kierującego działaniami ratowniczymi i realizuje zadania przez niego przydzielone, zgodnie z wypracowaną wspólnie taktyką działania. Kierujący akcją medyczną decyduje o utworzeniu sztabu medycznego pomagającego w gromadzeniu, przetwarzaniu i wypracowywaniu niezbędnych decyzji (zob. ryc.3). 


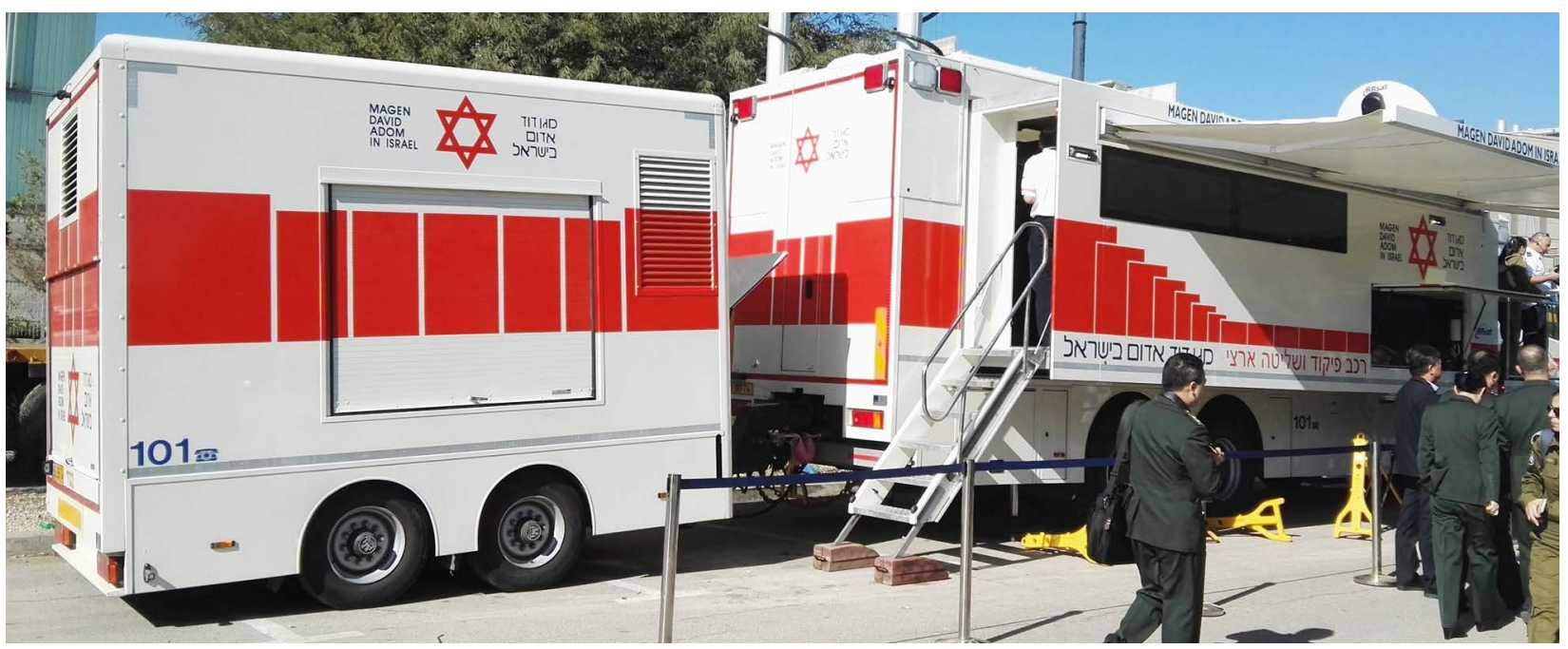

Figure 3. The medical command post (Tel Aviv, Izrael, 2016)

Rycina 3. Stanowisko dowodzenia dla służb medycznych (Tel Awiw, Izrael, 2016)

Source: The authors' archives.

Źródło: Archiwum własne.

The range of tasks and the field of action of the triage group in CBRNE/HAZMAT incidents expands and gets divided into two zones (warm and cold). Pre-triage may be performed in the hot zone for evacuation purposes. In biological incidents, pre-triage and triage are both done in hot zones while in CBRNE incidents pyrotechnic triage may be essential before the medical staff starts providing care to the casualties. Pre-triage is performed at the casualty collection point (CCP) in front of the so-called mass decontamination tent in the hot zone and repeated in the cold zone once the decontamination process is finished. After the evacuation from the danger zone, where providing any medical attention is impossible, triage teams wearing personal protection equipment perform triage according to the $A B C D E$ approach taking into consideration the impact of a hazardous agent on the casualty (element $E$ in the $A B C D E$ approach). This is how the right sequence and the scope of medical care to be provided, as well as the sequence and methods of decontamination are determined (see Figure 4).

The decontamination task force equipped with personal protection equipment supports firefighter-paramedics during the decontamination process and provides medical care. Some of the severely injured patients due to, e.g., blast injuries or poisoning require immediate medical care including life support (e.g., ventilation) during the decontamination process. At such an early stage, medical professionals (paramedics, doctors and nurses of the PRM system) may use antidotes (e.g., atropine) if a hazardous agent has been identified and the application of antidotes is medically justified.

The task force responsible for "treatment" performs triage, defines the scope of medical support which is given and prepares patients for transportation.
Zakres zadań i obszar działania grupy segregacyjnej triage w zdarzeniach CBRNE/HAZMAT ulega poszerzeniu i rozdzieleniu na dwie strefy działań (ciepłą i zimną). Pierwsza segregacja, którą można określić jako pre-triage, odbywać się może już w strefie gorącej i będzie realizowana na potrzeby ewakuacji. W zagrożeniach biologicznych wstępny i właściwy triage będzie wykonywany w strefie gorącej.

W incydentach CBRNE może pojawić się konieczność wykonania triage'u (rozpoznania) pirotechnicznego przed dopuszczeniem do ofiar personelu ratowniczego. Triage wstępny realizowany będzie w punkcie zbiórki poszkodowanych umieszczonym przed namiotem dekontaminacyjnym w strefie ciepłej, a następnie powtórzony w strefie zimnej po jej wykonaniu. Po ewakuacji ze strefy bezpośredniego zagrożenia, w której nie ma właściwie możliwości udzielania pomocy medycznej, zespoły segregacyjne zabezpieczone $w$ indywidualne środki ochrony dokonują segregacji zgodnie z podstawowymi algorytmami segregacyjnymi z uwzględnieniem wpływu czynnika niebezpiecznego na stan pacjenta (element $\mathrm{E}$ $w$ algorytmie $A B C D E$ ). Tym sposobem ustalona zostaje kolejność i zakres udzielania pomocy oraz kolejność i sposób wykonania dekontaminacji. Ten model postępowania zilustrowano na rycinie 4 .

Grupa zadaniowa "dekontaminacja" zabezpieczona w indywidualne środki ochrony udziela wsparcia ratownikom-strażakom podczas dekontaminacji i zabezpiecza pacjentów pod względem medycznym. Część poszkodowanych, będących w stanie ciężkim, np. w wyniku obrażeń powybuchowych lub zatrucia, wymaga zabezpieczenia medycznego podczas dekontaminacji, $w$ tym wykonania w jej trakcie czynności utrzymujących i wspomagających podstawowe funkcje życiowe (np. prowadzenie wentylacji czynnej). Na tym wstępnym etapie obecność medyków (ratowników medycznych, lekarzy i pielęgniarek systemu PRM) pozwala także na zastosowanie specyficznych odtrutek (np. atropiny), o ile ich użycie na wczesnym etapie jest uzasadnione z medycznego punktu widzenia, a niebezpieczna substancja została już zidentyfikowana. 


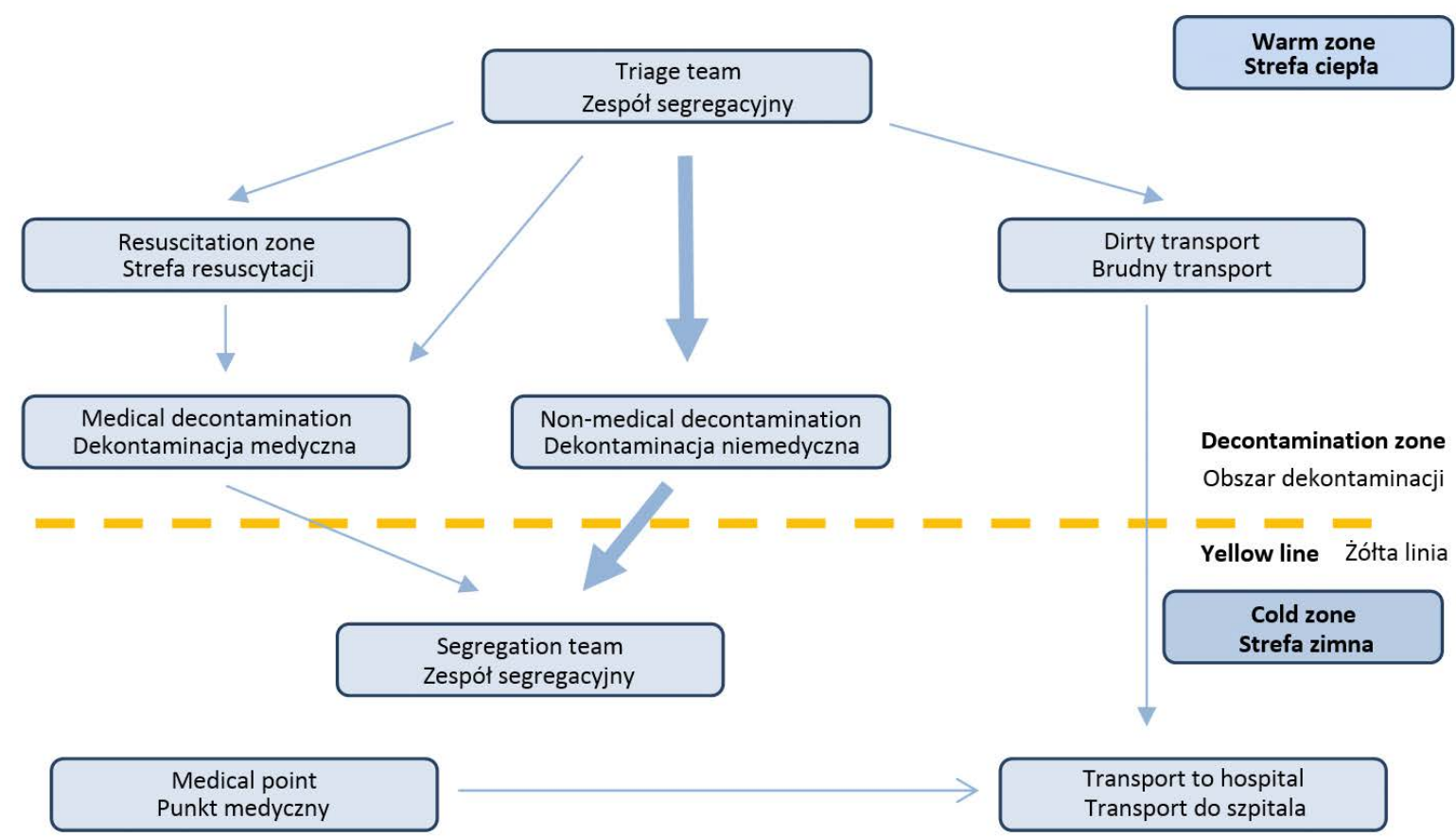

Figure 4. The organisation of medical response in the "warm zone"

Rycina 4. Organizacja działań ratunkowych w strefie ciepłej

Source: Own elaboration.

Źródło: Opracowanie własne.

The task force responsible for "transportation" or a person in charge of transportation, manages ambulances at the incident scene, supervises equipment of emergency medical teams, and supervises the sequence of transportation and safe patients' transport to transportation teams. Therefore, the "clean" and "dirty" transport from the incident scene to the "safety" task force, which ensures paramedics' safety and protection, is done. "Dirty" transport is understood as the transport of a contaminated or infectious patient. Such transport requires special precautionary measures, use of PPE protection or isolation and transport chambers.

Task force or function body called "reserve" is responsible for the smooth functioning of the tactical reserve for medical rescue. In the place where the forces and means of rescue of the KSRG system are grouped, there is a separate sector in which emergency medical services and resources are grouped and then transferred to place of the event. A research study by Melnikova et al. has indicated that early responders, including especially firefighters and police officers, are commonly injured in chemical incidents, which proves the necessity for setting up a "safety" task force to support all participants and respondents of the incident, including the National Firefighting and Rescue System and the police [22]. Evaluating the extent of biological danger by constant monitoring of the levels of substances present in the environment, gathering, processing and passing data to the medical operations coordinator and the medical professionals involved in the rescue operations is a priority for this task force. Moreover, the
W punkcie medycznym grupa zadaniowa odpowiedzialna za „leczenie" dokonuje triage'u właściwego pacjentów, ustala zakres czynności niezbędnych do wykonania na miejscu. Realizuje te zadania, stosując właściwe dla danego pacjenta metody leczenia i przygotowuje pacjentów do transportu.

Grupa zadaniowa "transport” lub osoba funkcyjna odpowiedzialna za transport organizuje bezpieczny ruch ambulansów w rejonie zdarzenia, kontroluje odpowiednie do zadania wyposażenie zespołów ratownictwa medycznego, przestrzega kolejności transportu i bezpiecznego sposobu przekazania pacjentów zespołom transportowym. Tym sposobem organizuje i kontroluje przebieg "Czystego" i „brudnego" transportu z miejsca zdarzenia do szpitali. „Brudny" transport rozumiany jest jako przewóz pacjenta skażonego lub zakaźnego. Taki transport wymaga zastosowania szczególnych środków ostrożności, zabezpieczenia w ŚOI lub wykorzystania komór izolacyjno-transportowych.

Grupa zadaniowa lub osoba funkcyjna "odwód" odpowiedzialna jest za sprawne funkcjonowanie odwodu taktycznego dla ratownictwa medycznego. W miejscu zgrupowania sił i środków ratownictwa systemu KSRG znajduje się wydzielony sektor dla sił i środków ratownictwa medycznego. Z tego miejsca dysponuje się nimi w miejsce zdarzenia w celu realizacji określonego zadania wynikającego z przyjętej taktyki działania.

Ze względu na stale istniejące zagrożenie dla bezpieczeństwa medyków i innych działających na miejscu służb uzasadnionym wydaje się wydzielenie w systemie zarządzania osoby funkcyjnej i grupy zadaniowej „bezpieczeństwo” mającej na celu zapewnie- 
group constantly monitors paramedics' physical and mental condition, and analyses their capabilities to perform assigned tasks considering the impact of PPE with the use of telemetry monitoring systems and to react accordingly in the case of emergency or physical/mental exhaustion that may disturb the completion of a given task.

\section{CBRNE/HAZMAT Rescue Task Force}

The State Emergency Medical System is required to respond effectively to new CBRNE/HAZMAT threats. Thus, new special units have been established both in the police and firefighting units, i.e., a counter-terrorist unit or a special rescue and firefighting unit including chemical and ecological rescue.

The solution is to establish the Rescue Task Force (RTF) in some of Hospital Emergency Departments, just like the Hazardous Area Response Team (HART) in Great Britain. HART units are made up of emergency medical personnel that is specially recruited and has gone through specialised training to provide medical care to the injured in a dangerous environment where conventional Emergency Medical Teams may fail. It is crucial to understand that HART units are to provide medical care to casualties in cooperation with other services, e.g., Fire and Rescue Services (FRS) in the UK, and are not to manage/handle the whole incident or an incident scene. Within the HART system, paramedics have been divided into more specific sections that respond to certain incidents, e.g., the Urban Search and Rescue (USAR) and the Tactical Medical Operations (TMO) [23-24].

The HART history goes back to 2004 when the Ambulance Service Association (ASA) and the Department of Health (in Great Britain) applied for a feasibility study to be conducted of the Emergency Medical Teams working within the inner safety cordon. As a result, a decision was made to investigate the possibility to train and equip the personnel of emergency medical services who could work safely in hazardous environments. Moreover, the terrorist bombings in London on 7 July 2005 [3], [21-22] triggered and accelerated the HART programme. HART units are based across England to support the EMS both locally and internationally.

The Rescue Task Forces would be based at ambulance stations in urban sites where specialised chemical and ecological rescue groups operate, and they would respond in cooperation with the Fire Service and support emergency departments and trauma centres. In towns and cities where the threat is minor, a solution is to train some members of the nie bezpieczeństwa i ochronę również ratownikom medycznym. Badania Melnikovej i wsp. wskazują, że najczęściej w zdarzeniach chemicznych zostają poszkodowani strażacy i policjanci. Fakt ten dodatkowo uzasadnia utworzenie grupy zadaniowej „bezpieczeństwo" jako wsparcia dla wszystkich - nie tylko KSRG i policji [22]. Monitorowanie zmiennego $\mathrm{w}$ czasie poziomu zagrożenia w środowisku, w którym prowadzone są działania medyczne, gromadzenie, przetwarzanie i przesyłanie informacji do KAM i działających medyków to podstawowe zadanie tej grupy. Dodatkowo monitoruje ona stan fizyczny i psychiczny ratowników medycznych, analizuje możliwości realizacji przez nich zadań, mając na uwadze wpływ stosowanych indywidualnych środków ochrony na ratowników medycznych przy wykorzystaniu telemetrycznych systemów monitorujących, a także interweniuje w sytuacji pojawiającego się dla nich zagrożenia czy niemożliwości wykonania zadania wynikającego z nadmiernego wyczerpania psychicznego czy fizycznego.

\section{Specjalistyczne grupy medyczne CBRNE/ HAZMAT}

Pojawiające się nowe zagrożenia CBRNE/HAZMAT wymagają odpowiedniego przygotowania systemu Państwowe Ratownictwo Medyczne do skutecznego reagowania w tego typu zdarzeniach. Podobnie jak w policji i straży pożarnej, obok rutynowo działających jednostek, konieczne stało się przygotowanie jednostek specjalistycznych, np. jednostek kontrterrorystycznych czy specjalistycznych jednostek ratowniczo-gaśniczych o profilu chemiczno-ekologicznym.

Rozwiązaniem jest utworzenie specjalistycznych grup zadaniowych (ang. Rescue Task Force, RTF) ratownictwa medycznego w wybranych stacjach pogotowia ratunkowego na wzór brytyjskich zespołów HART (ang. The Hazardous Area Response Team) [3]. Zespoły HART tworzone są przez specjalnie rekrutowany i przeszkolony personel medyczny, który zapewnia pomoc medyczną dla poszkodowanych/chorych, znajdujących się w niebezpiecznym środowisku, w którym nie mogą działać tradycyjne ZRM. Co istotne, zespoły te nie mają na celu zabezpieczenia całego zdarzenia czy miejsca, w którym do niego doszło, a jedynie prowadzenie działań medycznych wśród osób poszkodowanych wraz z innymi jednostkami. Przykładowo w Wielkiej Brytanii dodatkowo wprowadzono podział zespołów HART na sekcje dedykowane specyficznym grupom zdarzeń np.: Urban Search and Resce (USAR), Tactical Medical Operations (TMO) [23-24].

Historia zespołów HART sięga 2004 roku, kiedy to the Ambulance Service Association (ASA) i tamtejszy Departament Zdrowia (Wielka Brytania) wystąpili z wnioskiem o zbadanie możliwości pracy personelu Zespołów Ratownictwa Medycznego w wewnętrznym kordonie bezpieczeństwa. W rezultacie podjęto decyzję o zbadaniu możliwości wyszkolenia i wyposażania pracowników ZRM, którzy będą w stanie bezpiecznie pracować w takich warunkach. Prace nad formowaniem jednostki przyspieszyły zamachy w Londynie z 7.07.2005 r. [3], [21-22 ]. Jednostki HART są strategicznie rozlokowane na terenie kraju, aby zapewnić wsparcie systemu ratownictwa medycznego zarówno na poziomie lokalnym, jak i krajowym. 
medical professionals who are interested in this matter. Those professionals would then provide care in the first place till the chemical rescue group of the National Fire Services and the HART [3] arrive.

The main task of the CBRNE/HAZMAT Rescue Task Force would be to act individually, mainly in the case of biological incidents, or to support the operations of counter-terrorist units and special chemical and ecological rescue units. The scope of the CBRNE/HAZMAT Rescue Task Force's trainings would be more advanced compared to MET. Moreover, a flexible approach to human resources management allows establishing mixed task forces consisting of, e.g., a firefighter/police officer and a paramedic. In the event of a tactical threat, paramedics would provide medical treatment assisted by police officers, enabling them to act in the warm zone.
Rozsądne wydaje się, aby proponowane grupy były zorganizowane w stacjach pogotowia ratunkowego zlokalizowanych w ośrodkach miejskich, w których znajdują się specjalistyczne grupy ratownictwa chemiczno-ekologicznego. Miałyby wtedy możliwość reakcji wspólnie ze Strażą Pożarną oraz równocześnie stanowiły wsparcie dla oddziałów ratunkowych i centrów urazowych. W miastach o mniejszym zagrożeniu tego typu zdarzeniami optymalnym rozwiązaniem może być wyszkolenie części personelu medycznego, zainteresowanego tą problematyką. Personel ten byłby zmobilizowany i wykorzystywany w pierwszej kolejności do czasu przyjazdu jednostek ratownictwa chemicznego PSP i zespołów HART [3].

Zadaniem grup zadaniowych CBRNE/HAZMAT byłoby samodzielne działanie (głównie zagrożenia biologiczne) lub wsparcie jednostek kontrterrorystycznych i specjalistycznych jednostek ratownictwa chemiczno-ekologicznego w realizowanych przez nie zadaniach. Zakres wyszkolenia specjalistycznych grup zadaniowych CBRNE/HAZMAT byłby bardziej zaawansowany w porównaniu z przeszkoleniem rutynowo działających zespołów ratownictwa medycznego. Dodatkowo elastyczne podejście do procesu zarządzania personelem pozwalałoby na tworzenie na miejscu zdarzenia mieszanych grup zadaniowych np.: strażak/policjant i ratownik medyczny-ratownik. Przykładowo w sytuacji zagrożenia o podłożu taktycznym ratownicy medyczni udzielaliby pomocy medycznej poszkodowanym w obstawie funkcjonariuszy policji, co umożliwiłoby im już działania w strefie ciepłej.

\section{Środki ochrony indywidualnej (ŚOI)}

Aby przedstawiona powyżej taktyka działania mogła zostać zrealizowana, personel medyczny wymaga odpowiedniego wyposażenia. Decydującą rolę odgrywają w nim środki indywidualnej ochrony przed skażeniami i środki ochrony dróg oddechowych. Optymalnym rozwiązaniem dla ratownictwa medycznego jest uniwersalny ubiór ochronny zapewniający bezpieczeństwo w zdarzeniach o różnym charakterze (biologicznym, chemicznym, radiacyjnym). Badania prowadzone przez Zakład Medycyny Katastrof i Pomocy Doraźnej Uniwersytetu Jagiellońskiego Collegium Medicum pozwoliły na wypracowanie optymalnego współcześnie wyposażenia zespołów medycznych działających w zagrożeniu CBRNE/HAZMAT. Proponowany ubiór ochronny oprócz zapewnienia bezpieczeństwa, pozwala na wykonanie niezbędnych w ratowaniu życia i zdrowia medycznych czynności ratunkowych (MCR).

Punktem wyjścia w proponowanym sposobie zarządzania ryzykiem i bezpieczeństwem personelu medycznego działającego w myśl nowej taktyki jest podział indywidualnych środków ochrony przed skażeniami i środki ochrony dróg oddechowych na cztery grupy zgodnie z podziałem OSHA (Occupational Safety and Health Administration) [25-26]:

- Poziom A - kombinezon gazoszczelny z aparatem powietrznym,

- Poziom B - kombinezon ochronny z aparatem powietrznym,

- Poziom C - kombinezon ochronny z maską i filtropochłaniaczem/kapturem z wizjerem panoramicznym i urządzeniem nadmuchowo-wentylacyjnym,

- Poziom D - rutynowo stosowane ubranie ochronne i maska z filtrem P3. cal emergencies as the gas-tight suit does not allow performing medical procedures. Level $B$ protection is used in the National 
Firefighting and Rescue System. Technologically advanced thin but resistant suits with protective layers, complying with all the applicable safety requirements, a respiratory protection device with a mask-integrated communication unit and a liquid collection system create new opportunities for their safe use in the field of medical emergency. Current rules and regulations limit the application of breathing apparatus within the State Emergency Medical System (PRM). Protective suits are used at both levels B and $C$, but only level $C$ protection equipment can be used in medical rescue services where breathing apparatus is not included. The application of full-face masks with replaceable combined filters in the place of self-contained breathing apparatus (SCBA) expands the range/scope of emergency medical responses to CBRNE/ HAZMAT incidents (see Figure 5). For better breathing comfort, suits with an integrated hood and a visor compatible with a powered air respirator have come into common use (see Figure 6 and Figure 7). Increased air supply in the hood and slightly higher pressure inside the suit give more comfort of breathing to the user and, consequently, make the user feel safer. On a daily basis, the emergency medical responders use basic protective clothing, helmets, protective gloves, gloves and half-face masks of the P3 class which do not offer enough protection against hazardous materials, mainly bio-based ones (see Figure 8). Appropriate personal protective equipment combined with new strategies, the management system and the organisational structure would facilitate meeting the objectives.
Poziom zabezpieczenia A obecnie nie jest przewidziany do wykorzystywania rutynowego $\mathrm{w}$ ratownictwie medycznym. Współczesna konstrukcja kombinezonów gazoszczelnych nie pozwala na wykonywanie MCR. Poziom zabezpieczenia B wykorzystywany jest rutynowo w systemie KSRG. Nowoczesne pod względem technologicznym, cienkie a zarazem wytrzymałe tkaniny kombinezonów ze specjalnymi powłokami ochronnymi spełniające odpowiednie normy bezpieczeństwa, specjalna konstrukcja masek twarzowych z wbudowanymi systemami komunikacji i pobierania płynów stwarzają nowe możliwości ich bezpiecznego wykorzystania w obszarze ratownictwa medycznego. Poważnym ograniczeniem jest konieczność korzystania z aparatów powietrznych. Współcześnie obowiązujące przepisy ograniczają możliwości wykorzystania aparatów powietrznych w obszarze systemu PRM. Poziom zabezpieczenia $C$ pozwala na wykorzystanie w ratownictwie medycznym kombinezonów ochronnych jak w poziomie B, bez konieczności korzystania z aparatów powietrznych. Odejście od używania aparatów powietrznych na korzyść masek pełnotwarzowych z wymiennymi filtropochłaniaczami stwarza nowe możliwości reagowania ratownictwa medycznego na zagrożenia CBRNE/ HAZMAT (użycie tego sprzętu przez zespół medyczny prezentuje rycina 5). W celu poprawienia warunków oddychania coraz częściej wykorzystywane są kombinezony z zintegrowanym kapturem wyposażonym w wizjer panoramiczny przystosowany do współpracy z nadmuchowym urządzeniem filtrowentylacyjnym (zob. ryc. 6-7).

Zwiększony dopływ przefiltrowanego powietrza do kaptura i wytworzone tym sposobem niewielkie nadciśnienie w kombinezonie zwiększa komfort oddychania i poczucie bezpieczeństwa użytkownika. W codziennej praktyce ratowniczej personel medyczny wykorzystuje rutynowo stosowane ubranie ochronne, kaski, okulary ochronne, rękawiczki i półmaski z filtrem poziomu P3, zapewniające wystarczającą w warunkach codziennej praktyki ochronę przed materiałami niebezpiecznymi, głównie pochodzenia biologicznego (zob. ryc. 8).

Dzięki wykorzystaniu odpowiedniego wyposażenia ochronnego personelu medycznego oraz wyznaczeniu celu prowadzonych działań wypracowano nową taktykę oraz system zarządzania wraz z niezbędną do jego realizacji strukturą organizacyjną.

\section{Dyskusja}

Obecne i przyszłe wyzwania dla ratownictwa medycznego związane z kontaktem ratownika z materiałem niebezpiecznym lub pacjentem będącym pod jego wpływem (skażonym, infekcyjnym, napromieniowanym, zatrutym, zakażonym) wymagają zmiany podejścia systemu ratownictwa medycznego do problematyki CBRNE/HAZMAT. Wdrożenie nowej taktyki powinno być poprzedzone odpowiednim przygotowaniem personelu medycznego pod względem mentalnym, psychicznym, fizycznym, merytorycznym, a przede wszystkim wsparciem technicznym.

Dotychczasowa taktyka medyczna i sposób zabezpieczenia personelu medycznego w dobie współczesnych osiągnięć technicznych są już niewystarczające i - w ocenie autorów - wymagają gruntownych zmian. Idąc dalej, wzorem Policji i Państwowej Straży Pożarnej, niezbędne jest utworzenie specjalistycznych jednostek ratownictwa medycznego odpowiednio wyposażonych i przygotowanych do wykonywania medycznych czynności 


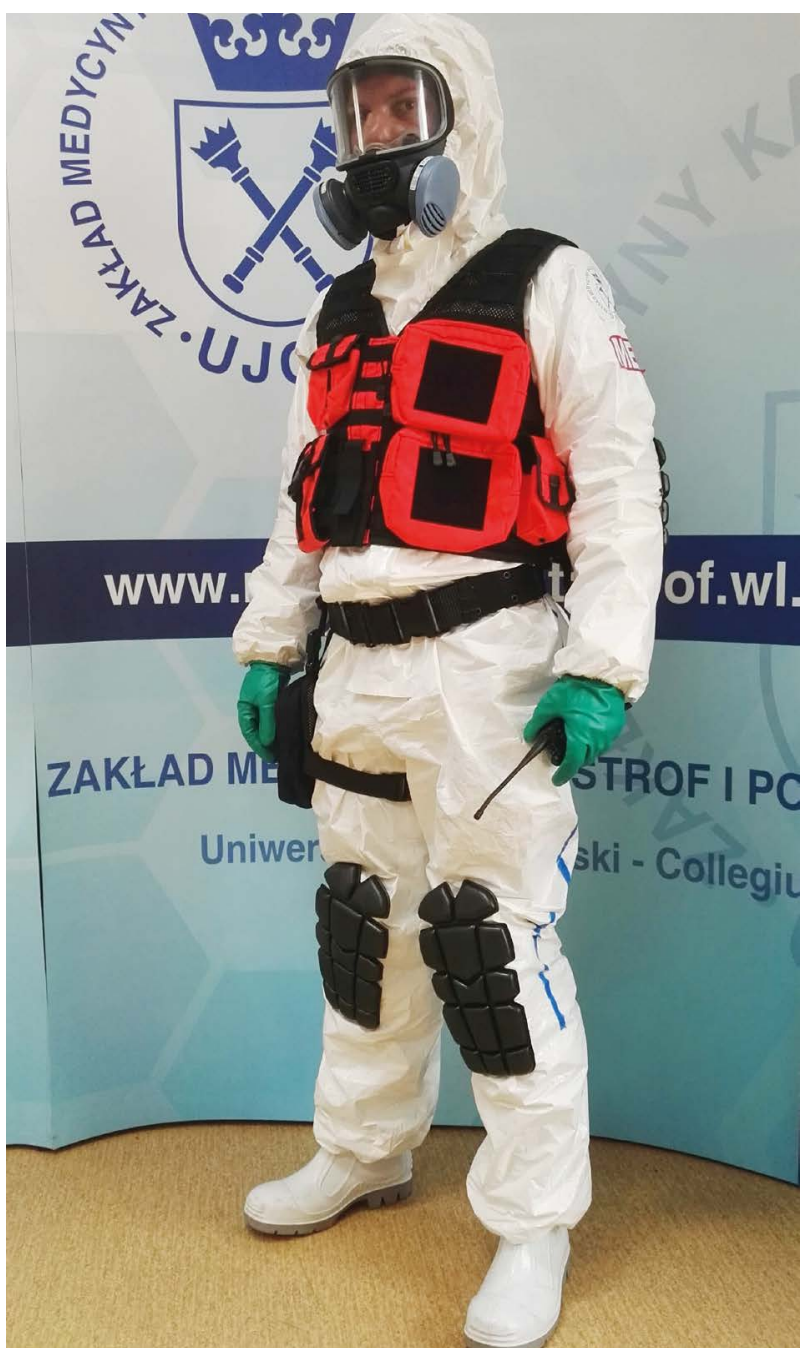

Figure 5. A paramedic wearing a protective suit and a full-face mask respirator

Rycina 5. Ratownik medyczny w kombinezonie ochronnym i masce pełnotwarzowej z filtrami

Source: The authors' archives.

Źródło: Archiwum własne.

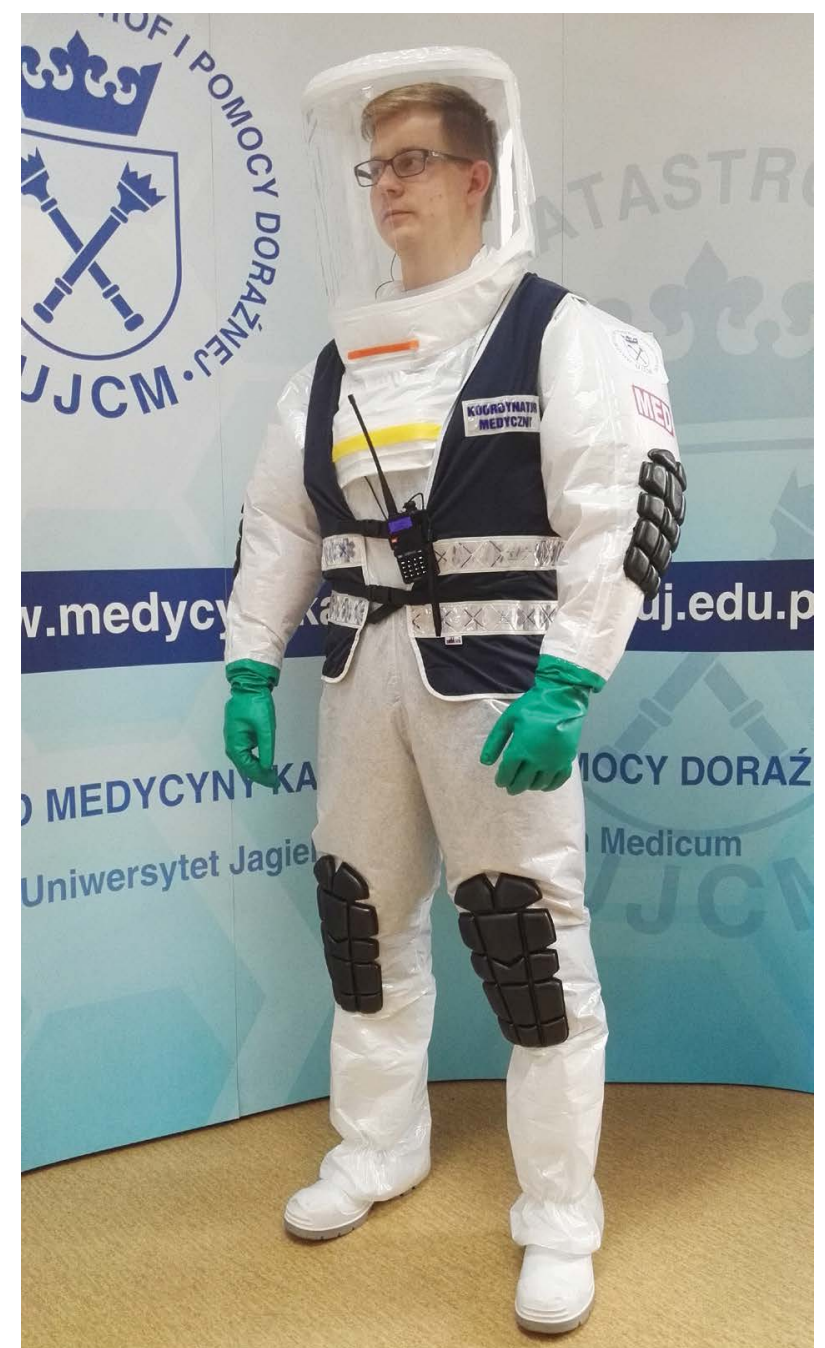

Figure 6. A paramedic wearing a protective suit with a hood and a wide visor integrated with a powered air respirator

Rycina 6. Ratownik medyczny w kombinezonie ochronnym z kapturem wyposażonym $w$ wizjer panoramiczny zintegrowany z nadmuchowym urządzeniem filtrowentylacyjnym

Source: The authors' archives.

Źródło: Archiwum własne.

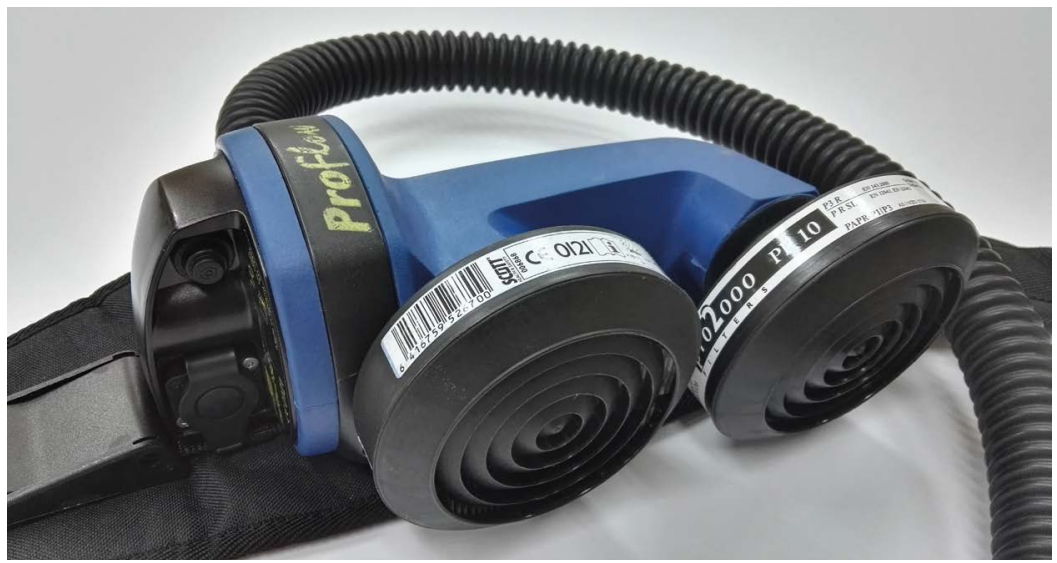

Figure 7. Scott Safety Proflow 2 EX Powered Air Respirator

Rycina 7. Nadmuchowe urządzenie filtrowentylacyjne Scott Proflow 2 S.C. z podłączonymi filtrami

Source: The authors' archives. / Źródło: Archiwum własne. 
ance with the tactics and strategies common for all the above services. Therefore, all services would improve their effectiveness or responses to such incidents. Then, the concept of a rescue system is no longer a combination of different services focused on their tasks but it forms a unitary whole which shares a common objective. Accessible and safe protection suits and respiratory protection equipment which enable performing medical interventions may influence and alter medical-rescue strategies/tactics. A division into safe and danger zones limits, or even prevents, performing medical rescue operations in the danger zone. For this reason, it is currently being replaced by a new approach which envisages flexible responses to incidents, including a risk analysis and a prognosis of benefits, limitations, capabilities, effects and costs.

The PPE of the National Emergency Medical Services system (PRM) enables providing pre-hospital and hospital medical care (in Hospital Emergency Departments), as well as in the departments of clinical toxicology, intensive care units and departments of infectious diseases. The application of PPE allows to respond to most biological, chemical and radiation events. Protective suits are simple and safe, and after having left the contaminated zone, unlike biological suits, the process of decontamination may start with the use of water and decontamination foam. Then, the suit can be taken off safely, with a minimal risk of secondary contamination. It is important to be able to take the suit off quickly and safely in situations where the paramedic's life and well-being are threatened. It also saves time to train professionals on how to use the suit properly and safely.

The management of human resources within the rescue system is competence-based which allows transfers between the units. Paramedics who are also full-time firefighters in the National Firefighting Rescue System are able to use level B protection equipment that, when combined with their medical knowledge, allows them to perform medical rescue operations in every operating area (pre-hospital, Hospital Emergency Departments, hospitals). This increases both the efficiency and performance.

The evaluation of available resources and PPE in CBRNE/HAZMAT incidents enables a flexible management of resources, i.e., transferring paramedics to respond in particular zones. For example, entering the hot zone may require level $\mathrm{B}$ protection; for triage to be performed at the casualty collection point (CCP), level $\mathrm{C}$ protection is needed; a decontamination process taking place in a special decontamination tent involves level B protection; and pre-triage at medical points requires level $D$ protection. While identifying the level of necessary competencies at the subsequent stages, the range of skills needed at a given moment may be identified. The hot zone evacuation and vertical decontamination (involving medical support) may require certified (qualified) first aid (Polish: Kwalifikowana Pierwsza Pomoc, KPP)* while triage at a casualty collection point and at a medical point, or decontamination of patients with a life-threatening illness, require emergency medical procedures treatment (MCR).* (medyczne czynności ratunkowe, MCR).

The use of advanced solutions applied in protective suits/ overalls with an integrated hood and a visor compatible with a powered air respirator enables medical professionals to provide medical treatment without the prior special and time consuming training. The suggested solutions allow for most of the necessary rescue procedures to be carried out at an early stage of patients' treatment. The suits with full-face respirator masks are ratunkowych w zagrożeniach CBRNE/HAZMAT, praktycznie w każdej ze stref, w ramach wspólnej dla wymienionych służb taktyki działania. Przy przyjęciu takich założeń zwiększa się również skuteczność reagowania przez wszystkie służby na wyżej wymienione zagrożenia, co w szerokim kontekście pozwala myśleć o systemie ratowniczym jako całości, a nie zbiorze podsystemów, skupiających się tylko na realizacji własnych celów.

Dzięki dostępowi do bezpiecznych, ale dających możliwości wykonywania MCR kombinezonów ochronnych i środków ochrony dróg oddechowych, zmianie może ulec taktyka ratowniczo-medyczna. Tradycyjny podział na strefy bezpieczną i niebezpieczną, który ograniczał (czy wręcz uniemożliwiał) działanie ratownictwa medycznego w strefie niebezpiecznej, zastępowany jest przez nową taktykę uwzględniającą elastyczne reagowanie na zagrożenia z uwzględnieniem analizy ryzyka i spodziewanych korzyści, ograniczeń i możliwości, efektów oraz kosztów.

Wyposażenie personelu medycznego systemu PRM w proponowane środki ochrony indywidualnej pozwala na bezpieczne postępowanie $z$ pacjentem zarówno $w$ ratownictwie przedszpitalnym, jak i na poziomie szpitalnego oddziału ratunkowego i dalej - na poziomie oddziału toksykologii klinicznej, intensywnej terapii czy oddziału chorób zakaźnych. Uniwersalność tych środków pozwala na zastosowanie ich w większości zdarzeń pochodzenia biologicznego, chemicznego i radiacyjnego. Do ich niewątpliwych zalet należą prostota wykonania i bezpieczeństwo użycia. Wyjście ze strefy skażonej pozwala - inaczej, niż w przypadku użycia kombinezonów biologicznych - na wykonanie dekontaminacji przy wykorzystaniu wody lub środków pianotwórczych, a następnie bezpieczne zdjęcie kombinezonu, ze zminimalizowanym ryzykiem wtórnego skażenia. Powyższe cechy mają szczególne znaczenie w sytuacjach zagrożenia życia i zdrowia ratownika - wówczas możliwość sprawnego rozebrania się z kombinezonu i bezpieczny dostęp do niego mogą odegrać decydującą rolę. Pozwala to także skrócić proces szkolenia personelu w zakresie obsługi kombinezonów i ich bezpiecznego wykorzystania.

Zarządzanie zasobami ludzkimi systemu ratowniczego opartego na wykorzystaniu posiadanych kompetencji pozwala na ich transfer pomiędzy jednostkami systemu. Ratownicy medyczni będący jednocześnie etatowymi strażakami KSRG mają możliwości wykorzystania ubrań ochronnych poziomu B i wiedzy ratownika medycznego podczas wykonywania medycznych czynności ratunkowych w każdym obszarze działania (ratownictwo przedszpitalne, SOR, oddział szpitalny). Takie podejście zwiększa wykorzystanie zasobów systemu, a przez to także jego efektywność i wydolność.

Ocena dostępnych poziomów kompetencji i zabezpieczenia w ŚOI na miejscu zdarzenia CBRNE/HAZMAT pozwala na elastyczne zarządzanie zasobami i kierowanie ratowników medycznych do realizacji zadań w poszczególnych strefach. Przykładowo, wejście do strefy gorącej może wymagać poziomu zabezpieczenia $B$, wykonanie triage'u w punkcie zbiórki poszkodowanych - poziomu zabezpieczenia C, prowadzenie dekontaminacji w specjalnie do tego przeznaczonym namiocie - poziomu zabezpieczenia B, wstępny triage w punkcie medycznym - poziomu D. Precyzując poziom niezbędnych kompetencji na kolejnych 
a practical solution for CBRNEmed groups to be used in pre-hospital conditions. They provide a better head protection as ballistic helmets, along with bulletproof vests and other safety solutions, increase the overall safety of paramedics.

In HAZMAT incidents, emergency medical services should be equipped with protective clothing that display insulating capacities, unlike the filtrating protective equipment used for military or counter-terrorist purposes. Further technological developments will give rise to a new type of gas-tight suits designed for medical and medical rescue purposes that meet the specific needs of medical professionals. The United States Department of Homeland Security has released a set of predictions considering the impacts of technologies on EMS responders, to be implemented by 2030 [27]. In the future, the EMT's gear will give ballistic and puncture protection, and will be equipped with a high visible mode to be used in the dark. Sensors will monitor EMTs' health status and their location in the field. By using exosuits (powered suits), future EMTs will be able to lift and move patients easily. The above solutions will have to be applied in gas-tight suits as well.

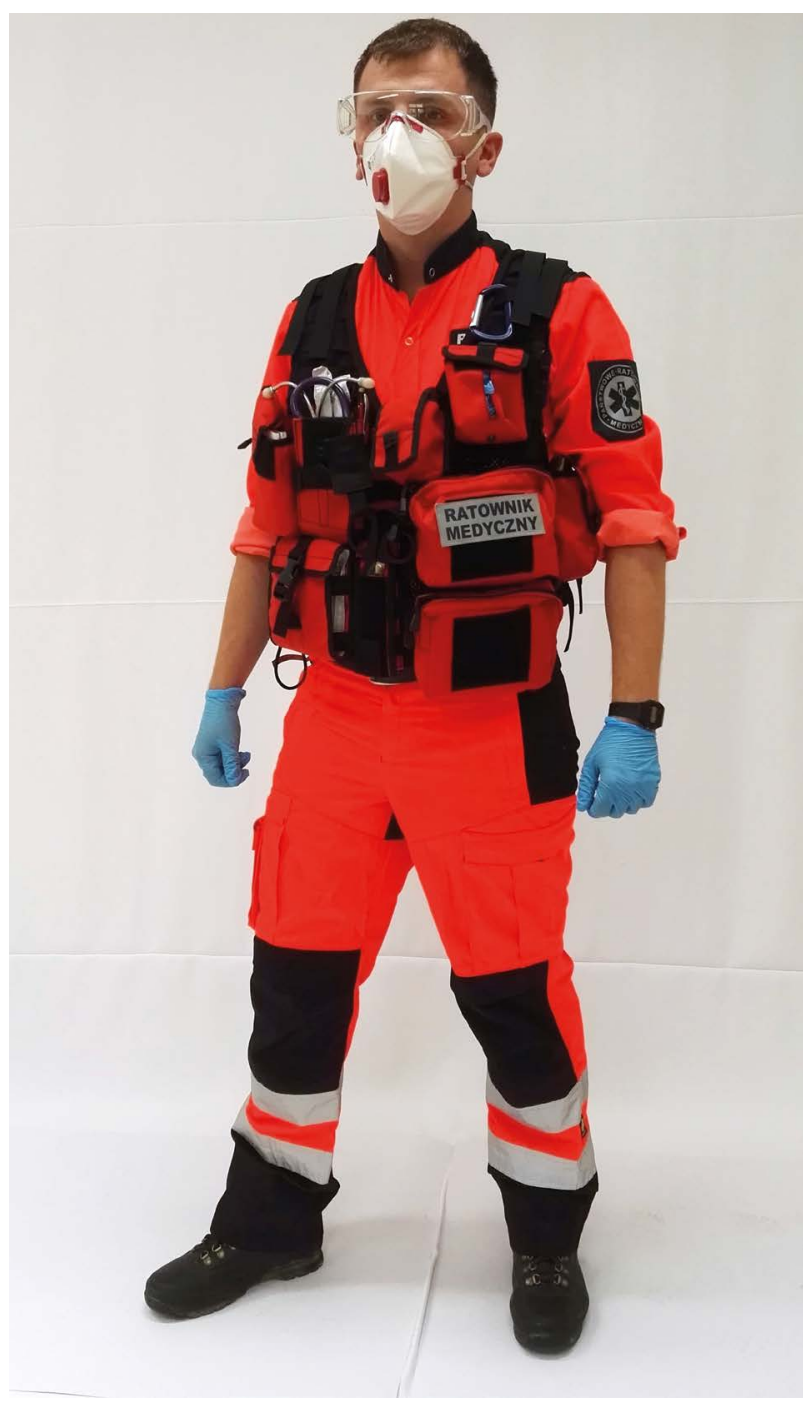

etapach, możemy określić, jaki zakres posiadanych umiejętności jest nam w danej chwili potrzebny. Ewakuacja ze strefy gorącej może wymagać zaangażowania ratowników na poziomie kwalifikowanej pomocy medycznej (KPP), triage w punkcie zbiórki poszkodowanych - na poziomie MCR, dekontaminacja pionowa - na poziomie KPP, dekontaminacja medyczna (pozioma) u pacjentów w zagrożeniu życia - na poziomie MCR, triage w punkcie medycznym - na poziomie MCR, itd.

Wykorzystanie nowoczesnych rozwiązań w postaci kombinezonów ochronnych z zintegrowanym kapturem i wizjerem panoramicznym współpracujących z nadmuchowym urządzeniem filtrowentylacyjnym umożliwia podjęcie działań przez personel medyczny bez specjalistycznego i czasochłonnego szkolenia. Zaproponowane rozwiązania pozwalają na wykonanie większości niezbędnych medycznych czynności ratunkowych w procesie wstępnego leczenia pacjentów. Kombinezony z maskami pełnotwarzowymi są praktycznym rozwiązaniem dla grup o charakterze taktycznym (CBRNEmed) do wykorzystania przede wszystkim w warunkach przedszpitalnych. To rozwiązanie umożliwia sprawne i wygodne poruszanie się w otwartym terenie. Dodatkowo pozwala na lepszą ochronę głowy poprzez wykorzystanie hełmów balistycznych i kamizelek kuloodpornych oraz innych rozwiązań zwiększających bezpieczeństwo ratownika medycznego.

Ze względu na charakter zagrożeń HAZMAT w ratownictwie medycznym preferowane są ubrania izolacyjne (mające zastosowanie w wojsku i jednostkach kontrterrorystycznych). Niewątpliwie dalszy postęp techniczny pozwoli na wypracowanie nowego typu kombinezonów gazoszczelnych do zastosowania w obszarze medycyny i ratownictwa medycznego, uwzględniającego potrzeby personelu medycznego. Departament Bezpieczeństwa Wewnętrznego USA opublikował prognozowany scenariusz dotyczący wpływu innowacji technologicznych na pracę ratownictwa medycznego do 2030 roku [27]. Przewiduje on, że odzież ochronna ratowników będzie wykonana z materiałów inteligentnych z funkcją ochrony przed bronią palną i białą. Kombinezon będzie posiadał tryb wysokiej widoczności w warunkach działań nocnych lub w zaciemnionych miejscach. Osobiste czujniki bio-medyczne będą monitorować stan ratownika (przypominając chociażby o potrzebie przyjęcia płynów) oraz jednocześnie będą pokazywały aktualną lokalizację ratownika w akcji. Ponadto przy pomocy egzoszkieletów ratownicy mogliby podnosić/przenosić pacjentów z mniejszym wysiłkiem. Podobne rozwiązania będą musiały być wprowadzone także do nowych kombinezonów gazoszczelnych.

Figure 8. A paramedic wearing level D protective clothing

Rycina 8. Ratownik medyczny w ubraniu ochronnym poziomu zabezpieczenia D

Source: The authors' archives.

Źródło: Archiwum własne. 


\section{Conclusions}

Advances in personal protective equipment to prevent contamination and respiratory protective equipment adapted for medical emergencies have encouraged changes in the tactics of the State Emergency Medical System (PRM) as they let emergency teams to operate in previously inaccessible areas. Simple, safe and tested solutions allow medical professionals to cooperate safely with counter-terrorism units and the Fire Services. Emergency teams will be able to provide care at early stages of CBRNE/HAZMAT incidents, which may save many lives.

\section{List of abbreviations / Wykaz skrótów}

\begin{abstract}
CBRNE chemical, biological, radiological, nuclear, and explosives incident

CRESZ (Centrum Reagowania Epidemiologicznego Sił Zbrojnych RP) - Epidemiological Response Centre of the Polish Armed Forces

FRS Fire and Rescue Services

HART Hazardous Area Response Team

HAZMAT hazardous materials incident

KPP (kwalifikowana pierwsza pomoc) qualified first aid - a range of first aid procedures that can be performed by a fireman rescuer (KSRG), based on standardized rescue equipment (PSP-R1) / zakres procedur z obszaru pierwszej pomocy możliwy do wykonania przez ratownika-strażaka systemu KSRG w oparciu o wystandaryzowany sprzęt ratunkowy (Zestaw PSP-R1)
\end{abstract}

\section{Literature / Literatura}

[1] Ustawa z dnia 24 sierpnia 1991 r. o ochronie przeciwpożarowej (Dz.U. $1991 \mathrm{Nr}$ 81, poz. 351).

[2] Rozporządzenie Ministra Spraw Wewnętrznych i Administracji z dnia 3 lipca 2017 r. w sprawie szczegółowej organizacji krajowego systemu ratowniczo-gaśniczego (Dz.U. 2017 poz. 1319).

[3] Trzos A., Ratownictwo Medyczne wobec współczesnych zagrożeń, Elamed Media Group, Katowice 2019.

[4] Harmata W., Witczak M., Rozpoznanie skażeń w Polsce - aktualny stan wiedzy, BiTP 2018, 52(4), 20-45, https:// dx.doi.org/10.12845/bitp.52.4.2018.2.

[5] Kopczewski R., Nowacki G., Zakrzewski B., Zagrożenia chemiczne i ekologiczne podczas przewozu drogowego towarów niebezpiecznych, „Bezpieczeństwo i ekologia” 2017, 9.

\section{Wnioski}

Rozwój środków indywidualnych ochrony przed skażeniami i środków ochrony dróg oddechowych przystosowanych do wykorzystania przez personel medyczny umożliwia obecnie zmianę taktyki działania systemu PRM. Dzięki niemu możliwe jest zaangażowanie zespołów medycznych w obszarach dotychczas dla nich niedostępnych. Proste, bezpieczne i sprawdzone rozwiązania pozwalają na zabezpieczenie personelu medycznego na poziomie wystarczającym do podjęcia współdziałania z operatorami policji jednostek kontrterrorystycznych i ratownikami KSRG w ramach wspólnej taktyki działania. Szanse na uratowanie ofiar incydentów CBRNE/HAZMAT rosną dzięki możliwości zaangażowania medyków we wcześniejszych fazach działań ratowniczych.

KSRG (Krajowy System Ratowniczo-Gaśniczy) - The National Firefighting and Rescue System

MCR (medyczne czynności ratunkowe) - emergency medical procedures - a range of advanced medical procedures for self-implementation by a paramedic of the PRM system in Poland / zakres czynności medycznych możliwych do samodzielnego wykonania przez ratownika medycznego systemu PRM w Polsce

OSHA Occupational Safety and Health Administration PRM (Państwowe Ratownictwo Medyczne) - The State Emergency Medical System

RTF Rescue Task Force

SCBA self-contained breathing apparatus

ZDR (zakład dużego ryzyka) high-hazard worksite
[6] Arnold J. L., Disaster medicine in the 21st century: future hazards, vulnerabilities, and risk, "Prehospital and Disaster Medicine" 2002, 17(1),3-11, https://doi.org/10.1017/ S1049023X00000042.

[7] Raport o stanie bezpieczeństwa w Polsce w 2016 roku, MSWiA, 300, https://bip.mswia.gov.pl/bip/, [dostęp: 30.06.2019].

[8] Mortelmans L.J.M., Gaakeer M.I., Dieltiens G., Anseeuw K., Sabbe M.B., Are Dutch Hospitals Prepared for Chemical, Biological, or Radionuclear Incidents? A Survey Study, "Prehospital and Disaster Medicine" 2017, 32(5), 483-491, https://doi.org/ 10.1017/S1049023X17006513.

[9] Jama T.J., Kuisma M.J., Preparedness of Finnish Emergency Medical Services for Chemical Emergencies, "Prehospital 
and Disaster Medicine" 2016, 31(4), 392-396, https://doi. org/10.1017/S1049023X16000546.

[10] Olivieri C., Ingrassia P.L., Della Corte F., Carenzo L., Sapori J.M., Gabilly L., Segond F, Grieger F., Arnod-Prin P., Larrucea X., Violi C., Lopez C., Djalali A., Hospital preparedness and response in CBRN emergencies: TIER assessment tool, "European Journal of Emergency Medicine" 2017, 24(5), 366-370, https://doi.org/10.1097/MEJ.0000000000000399.

[11] Razak S., Hignett S., Barnes J., Emergency Department Response to Chemical, Biological, Radiological, Nuclear, and Explosive Events: A Systematic Review, "Prehospital and Disaster Medicine" 2018, 33(5), 543-549, https://doi. org/10.1017/S1049023X18000900.

[12] Levitin H. W., Siegelson H. J., Hazardous Materials Emergencies, w: Disaster Medicine, wyd. 2, D. E. Hogan, J.L. Burstein (red.), Wolters Kluwer, Lippincott Williams \& Wilkins, Philadelphia 2007, 311-325.

[13] Chernobyl's Legacy. Health, Environmental and Socio-Economic Impacts and. Recommendations to the Governments of Belarus, the Russian Federation and Ukraine https://www.iaea. org/sites/default/files/chernobyl.pdf [dostęp: 30.06.2019].

[14] Awaria w TMI http://atom.edu.pl/index.php/bezpieczenstwo/inne-wypadki/three-mile-island-1979.html [dostęp: 1.07.2019]

[15] The Fukushima Daiichi Accident https://www-pub.iaea. org/MTCD/Publications/PDF/Pub1710-ReportByTheDG-Web.pdf [dostęp: 1.07.2019].

[16] Byers M., Russel M., Lockey D.J., Clinical care in the „Hot Zone”, “Emergency Medicine Journal“ 2008, 25, 108-112, https://doi.org /10.1136/emj.2006.037689.

[17] Kumar V., Goel R., Chawla R., Silambarasan M., Sharma R.K., Chemical, biological, radiological, and nuclear decontamination: Recent trends and future perspective, "Journal of Pharmacy and Bioallied Sciences" 2010, 2, 220-238, https://doi.org/10.4103/0975-7406.68505.
[18] Hood E., The Tokyo Attacks in Retrospect Sarin Leads to Memory Loss, "Environmental Health Perspectives" 2001, 109(11), A542, https://doi.org /10.1289/ehp.109-a542a.

[19] Nowiczok. Jak Rosjanie opracowali najbardziej śmiercionośne trucizny na świecie? https://www.newsweek.pl/wie$\mathrm{dza} /$ nauka/nowiczok-siergiej-skripal-otruty-rosyjska-trucizna/3xq6stv, źródło: PAP [dostęp: 29.06.2019].

[20] Arnold J.L., Dembry L., Tsai M.C. i wsp.: Recommended modifications and applications of the Hospital emergency Incident Command System for Hospital emergency management, "Prehospital and Disaster Medicine" 2005, 20(5), 290-300, https://doi.org/ 10.1017/S1049023X00002740.

[21] Levitin H.W., Siegelson H.J., Hazardous Materials Emergencies, w: Disaster Medicine. Second Edition, D.E. Hogan, J.L. Burstein (red.), Wolters Kluwer/Lippincott Williams \&Wilkins, 2007, 311-325.

[22] Melnikova N., Wu J., Orr M., Acute Chemical Incidents With Injured First Responders, "Disaster Medicine and Public Health Preparedness" 2018, 12(2), 211-221, https://doi. org /10.1017/dmp.2017.50.

[23] www.nwas.nhs.uk/our-services/managing-major--incidents/hazardous-area-response-team-(hart)/\#. Wg2DT4_ WzIU [dostęp: 29.06.2019].

[24] www.ambulancehart.org.uk [dostęp: 29.06.2019].

[25] https://www.osha.gov/dts/osta/otm/otm_viii/otm_viii_1. html [dostęp: 2.07.2019].

[26] Trzos A., Łyziński K., Długosz K., Indywidualne środki ochrony dla ratownictwa medycznego, „Na Ratunek” 2018, vol. 4, 22-28.

[27] Future of First Response - Vision for Emergency Medical Services https://www.youtube.com/watch?v=VHuzyjsvScl [dostęp: 2.07.2019].
ARKADIUSZ TRZOS, PH.D. - acting Head of the Department of Disaster Medicine and Emergency Care at the Jagiellonian University Medical College. He specialises in disaster medicine, rescue medicine and extreme medicine. co-author and scientific editor of the book entitled Ratownictwo medyczne wobec współczesnych zagrożeń (Emergency Medical Services and Contemporary Threats).

KAROL ŁYZIŃSKI, M.SC. - medical rescue worker at the Kraków Emergency Medical Services; Assistant at the Department of Disaster Medicine and Emergency Care, the Jagiellonian University Medical College; Ph.D. student at the Faculty of Health Sciences, the Jagiellonian University Medical College.

KAMIL JUROWSKI, PH.D. - specialises in toxicology, mass spectrometry, chromatography, lipid biochemistry, clinical biochemistry, analytical biochemistry.
DR ARKADIUSZ TRZOS - p.o. Kierownik Zakładu Medycyny Katastrof i Pomocy Doraźnej Uniwersytetu Jagiellońskiego Collegium Medicum. Specjalizuje się w: medycynie katastrof, medycynie ratunkowej, medycynie ekstremalnej. Współautor i redaktor naukowy publikacji pt. Ratownictwo medyczne wobec współczesnych zagrożeń.

MGR KAROL ŁYZIŃSKI - ratownik medyczny w Krakowskim Pogotowiu Ratunkowym, asystent w Zakładzie Medycyny Katastrof i Pomocy Doraźnej Uniwersytetu Jagiellońskiego Collegium Medicum, doktorant na Wydziale Nauk o Zdrowiu Uniwersytetu Jagiellońskiego Collegium Medicum.

DR KAMIL JUROWSKI - specjalności: toksykologia, spektrometria mas, chromatografia, biochemia lipidów, biochemia kliniczna, biochemia analityczna. 